EL RECONOCIMIENTO INDÍGENA A PARTIR DE LAS EXPERIENCIAS CON MEDIOS DE COMUNICACIÓN EN EL CABILDO NASA UBICADO EN LA CIUDAD DE BOGOTA D.C, COLOMBIA

Adriam Gómez Bastidas

Universidad NaCional de La Plata

Facultad de Periodismo y Comunicación Social

Maestría en Periodismo y Medios de Comunicación 


\section{EL RECONOCIMIENTO INDÍGENA A PARTIR DE LAS EXPERIENCIAS CON MEDIOS DE COMUNICACIÓN EN EL CABILDO NASA UBICADO EN LA CIUDAD DE BOGOTA D.C, COLOMBIA}

Adriam Gómez Bastidas

Asesor

Dra. Mónica Beatriz Lacarrieu

Trabajo presentado para optar por el título de Magíster en Periodismo y Medios de Comunicación

Universidad Nacional de La Plata

Maestría en Periodismo y Medios de Comunicación 
Nota de Aceptación

Jurado

Jurado 


\section{AGRADECIMIENTOS}

Resulta importante reconocer a toda la comunidad indígena Nasa en general, especialmente a la radicada en la ciudad de Bogotá, totalmente admirado por sus saberes, por brindar un entorno fraternal, a ellas, y a ellos, desearles siempre resistencia y consolidación ancestral. Valorar, y apreciar a Mónica Lacarrieu por su prudencia y apoyo incondicional durante este proceso personal y profesional.

Quiero destacar a la Universidad Nacional de La Plata por brindarme un espacio para mi formación académica y hacer que mi pasión por el periodismo creciera inmensamente, y no puedo olvidarme de todo un país, la Argentina, su gente, quienes aportaron para la consolidación de mis sueños, de mi carácter, siendo guías que mostraron el camino de la perseverancia, siempre agradecido con el sur, volveremos. 


\section{DEDICATORIA}

A mi Madre, mi hija, tía, y abuela, por tantas sonrisas y amor. 


\section{CONTENIDO}

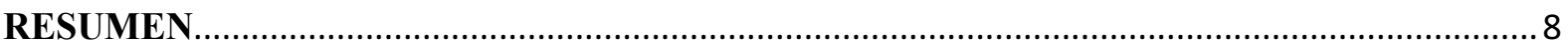

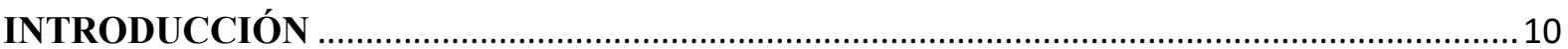

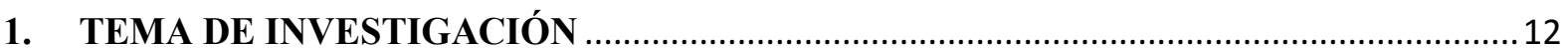

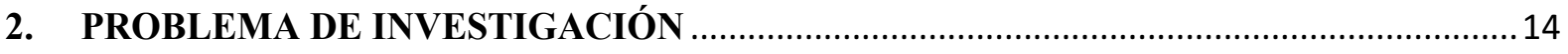

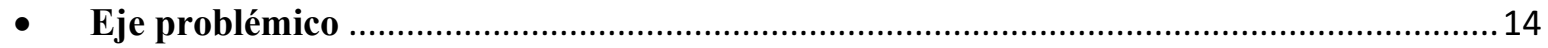

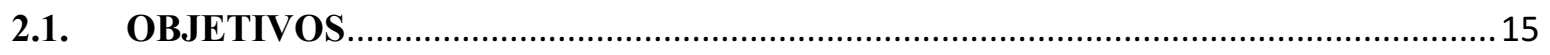

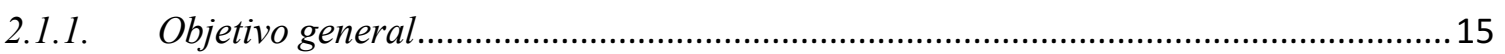

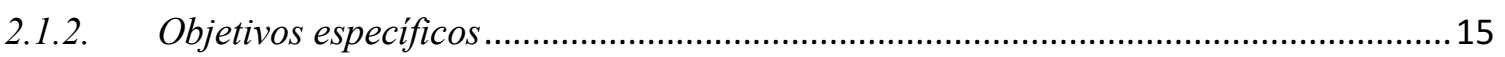

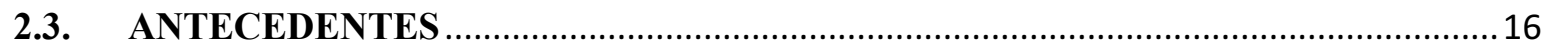

2.3.1. Perspectivas sobre el estado de comunidades indígenas en Bogotá ............................. 16

2.3.2. Diálogos y divergencias entre medios de comunicación y prácticas identitarias de los

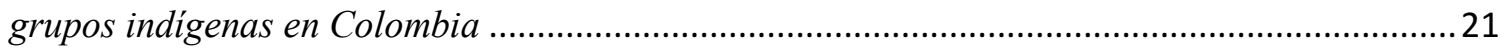

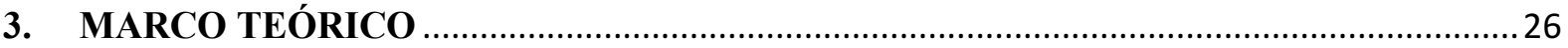

3.1. Del reconocimiento y la representación de las prácticas identitarias y culturales de las comunidades indígenas en Colombia

3.2. Significaciones de reconocimiento y menosprecio. Aproximaciones a sus categorías subyacentes

3.3. Sobre representación y reconocimiento: miradas a la relación entre medios de

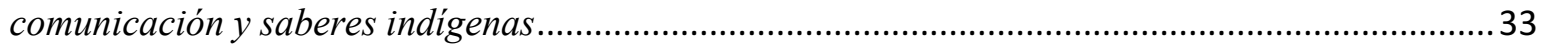

3.4. Acercamientos a los lugares de enunciación en el devenir indígena Nasa .......................... 36

3.5. La producción visual como apuesta ético-politica por el reconocimiento .............................38

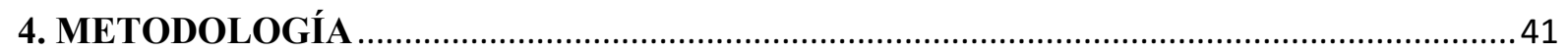

4.1. Investigación cualitativa y sistematización de experiencias ...................................................... 41

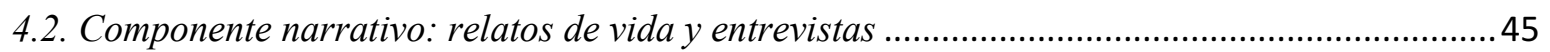

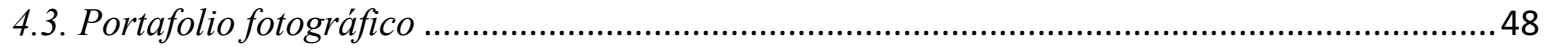

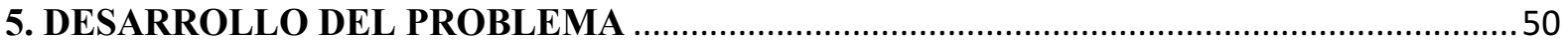

5.1. Acerca de la comunidad y cabildo indígena Nasa en Bogotá.................................................... 50

5.2. Configuraciones de reconocimiento y menosprecio en narrativas del cabildo Nasa de Bogotá

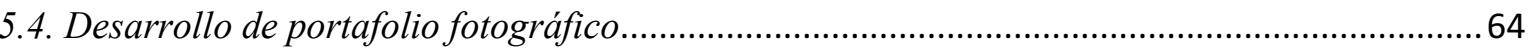

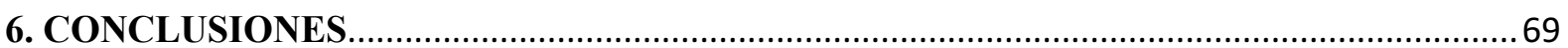

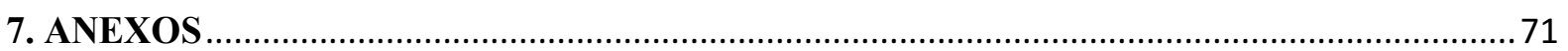

7.1 Formato de entrevista semiestructurada 1 ............................................................................. 71 


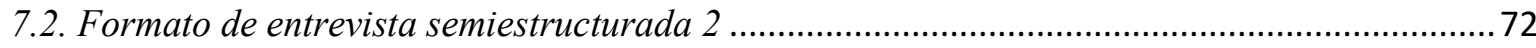

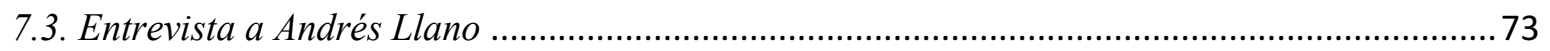

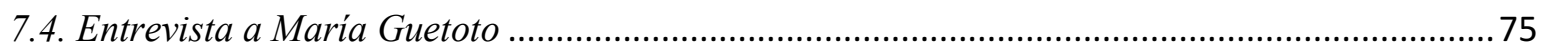

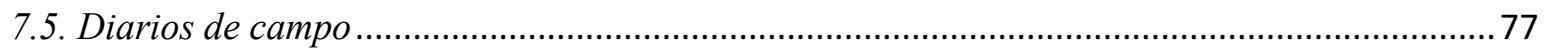

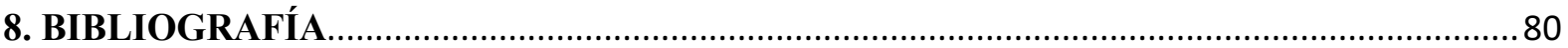




\section{RESUMEN}

La presente investigación explora los modos de reconocimiento existentes en el cabildo indígena Nasa de Bogotá y su vínculo con la producción discursiva de los medios de comunicación tradicionales y masivos para la comprensión de tres relatos de vida de hombres y mujeres pertenecientes a esta comunidad.

Para ello, se realiza una indagación frente al estado actual del movimiento social indígena con énfasis en el grupo étnico Nasa de Bogotá que busca caracterizar y comprender las percepciones y experiencias que hombres y mujeres poseen en torno a sus procesos de interacción con recursos audiovisuales.

Lo anterior con miras al desarrollo y divulgación de un portafolio fotográfico que, como producción estética, problematiza en torno a las significaciones propias del devenir indígena a partir de las prácticas de reconocimiento ancestral.

PALABRAS CLAVE: Reconocimiento, indígenas, Nasa, Medios de comunicación. 


\begin{abstract}
This research explores the modes of recognition that exist in the Nasa Indigenous Lobby of Bogota and its link to the discursive production of traditional and mass media for the understanding of three life stories of men and women belonging to this community.

For that, an analysis is carried out against the current state of the indigenous social movement with an emphasis on the Nasa ethnic group in Bogota that seeks to characterize and understand the perceptions and experiences that men and women possess around their processes of interaction with audiovisual resources.

This with a view to the development and dissemination of a photographic portfolio that, as an aesthetic production, problematizes around the significances of indigenous becoming based on ancestral recognition practices.
\end{abstract}

KEY WORDS: Recognition, Indigenous, Nasa, Media. 


\section{INTRODUCCIÓN}

Las poblaciones indígenas en Colombia son quizá de los grupos identitarios con mayores cargas históricas de violencia y estigmatización en el país. Por efectos del conflicto armado interno y, en especial, por problemáticas relacionadas como el desplazamiento forzado, entre otras. De acuerdo con el Observatorio de Memoria y Conflicto del Centro Nacional de Memoria Histórica (2019), entre los años 1958 a 2019 se registran más de 5.011 víctimas indígenas en el marco de los actos de barbarie a manos de distintos grupos armados. De ellas, aproximadamente 2.300 corresponden a hechos victimizantes como el asesinato selectivo ${ }^{1}$.

Lo anterior, permite contextualizar grosso modo la situación actual de la comunidad indígena Nasa que fundamenta esta investigación. Si bien los abordajes teóricos y analíticos respecto a la importancia de la pluralidad étnica en Colombia resultan ser con frecuencia amplias, la problematización respecto a sus vínculos con el componente discursivo en medios de comunicación al igual que sus prácticas identitarias en función de este elemento, son de profunda relevancia.

Así pues, la presente investigación aborda desde los desarrollos conceptuales de Honneth (1997), los modos de reconocimiento y, seguidamente, de menosprecio, que están imbricados en las construcciones identitarias del devenir indígena Nasa en Bogotá con especial análisis en el cabildo indígena ubicado en la capital del país.

Para ello, se desarrolla un planteamiento del problema que permite fundamentar las búsquedas epistemológicas sobre esta comunidad a la par que se sientan las bases para la consolidación de un compendio de producciones visuales a manera de portafolio fotográfico que, anexo al documento en mención, permite profundizar en este cuestionamiento.

Seguidamente, se propone una mirada al estado del arte de la cuestión que compromete un abordaje conceptual de investigaciones anteriores cuyo eje problémico ha sido las comunidades indígenas, al igual que la relación entre medios y producciones audiovisuales con las prácticas identitarias.

Posterior a ello, se precisa el desarrollo teórico que comprende un esbozo de los principales postulados que sustentan la investigación. Allí se precisan las categorías conceptuales tales

\footnotetext{
${ }^{1}$ Información recuperada de: https://centrodememoriahistorica.gov.co/pueblos-indigenas-victimas-de-violenciasde-larga-duracion/
} 
como el reconocimiento, el menosprecio y las prácticas identitarias y culturales que dan lugar a la problematización sobre los lugares de enunciación y las apuestas políticas por el reconocimiento emergentes del devenir indígena Nasa en contextos urbanos.

El marco metodológico constituye la columna vertebral de la investigación cuyo fin precisa el direccionamiento del ejercicio investigativo. Para ello, se acude a elementos como la investigación cualitativa y su arista práctica: la sistematización de experiencias que permite registrar de manera puntual los hallazgos y discusiones salientes de la praxis investigativa.

Finalmente, se presenta el desarrollo o sistematización de dicha experiencia investigativa asociada con el trabajo de campo realizado dentro del cabildo indígena Nasa en Bogotá el cual considera el componente mediático, visual, pero también sintiente de la comunidad en cuestión.

Lo anterior, devela una serie de conclusiones y posibilidades en las cuales derivan los modos de reconocimiento y, en especial, el derecho y la solidaridad como dos aspectos fundamentales para comprender los encuentros y desencuentros entre este grupo étnico y los medios de comunicación nacional.

Dadas las aproximaciones a esta labor investigativa, se espera que constituya un significativo aporte al campo de los estudios en periodismo en consonancia con distintos enfoques inter y transdisciplinares que permitan consolidar no solo un estado del problema en pleno sino abrir nuevas alternativas para la acción directa y dialógica en contextos socioculturales. 


\section{TEMA DE INVESTIGACIÓN}

La presente investigación se ocupa de las prácticas sociales, identitarias y culturales que configuran el reconocimiento ${ }^{2}$ de la comunidad indígena Nasa, en especial, a partir del acercamiento a las narrativas de vida de 4 integrantes del cabildo ${ }^{3}$ Nasa ubicado en la ciudad de Bogotá, Colombia.

Desde allí, la investigación plantea un análisis a dos perspectivas: una primera mirada desde la configuración de dicho reconocimiento proveniente de la comunidad y su pensamiento ancestral y una segunda concebida dado el posicionamiento que adquieren los medios de comunicación respecto a las prácticas de resistencia y salvaguarda de las costumbres ancestrales. Lo anterior, con miras a situar en el plano de la discusión sobre la relación entre medios de comunicación, cultura y poblaciones, los lugares de enunciación desde los cuales se abordan los discursos mediáticos y la pluralidad étnica.

En consecuencia, el ejercicio narrativo de los 4 integrantes del cabildo Nasa en mención, relaciona dos aristas de comprensión a saber: los relatos de reconocimiento que aluden al lugar de los sujetos en su comunidad, considerando sus prácticas de autonomía, resistencia, unidad, autocuidado y pertenencia a su grupo identitario y los relatos de menosprecio relacionados con los modos de estigmatización y violencia simbólica que se ejercen desde el discurso y la representación, principalmente en los medios de comunicación nacional.

Dicha noción de representación está sostenida a partir de un problema fundamental del discurso -en este caso audiovisual- desde el cual, se reproducen distorsiones en las realidades sociales que acentúan una reproducción fidedigna de estereotipos e imaginarios ya legitimados históricamente como estrategias de verosimilitud estética, informativa, etc. En este orden de ideas, la representación no refiere precisamente a una "puesta en escena de" "sino a quiénes y cómo enuncian en lugar de"; en palabras concretas, las apuestas por la representación apuntan a establecer un continuum de lógicas dominantes donde permanece una lucha de clases que invisibiliza a algunos y posiciona en su cumbre a otros. Sin embargo, en lo que se refiere a la

\footnotetext{
${ }^{2}$ Comprendida en términos de Honneth (1997), como la instancia de conflictividad social en la cual el individuo y la colectividad construyen su identidad, dado que es allí donde los individuos confrontan sus percepciones sobre sí mismos con los lenguajes morales sobre la convivencia para establecer una adscripción identitaria, un ideal de pertenencia o apropiación.

${ }^{3}$ Unidad fundamental de gobernabilidad indígena con funciones de manejo y administración de los territorios propios de las comunidades autóctonas.
} 
representación desde esta postura epistemológica, también hay un reforzamiento a las dinámicas de resistencia por parte de grupos históricamente subalternos, pues:

Aunque todos los estereotipos negativos sean hirientes, no todos ejercen el mismo poder en el mundo. Hablar de manera simplista y general sobre estereotipos deja de lado una distinción crucial: hay estereotipos sobre ciertas comunidades que simplemente hacen que el grupo al que se hace referencia se sienta mal, pero esa comunidad tiene el poder social para combatirlos y resistir... (Shohat y Stam, 2002, p. 192)

En este sentido, tanto el reconocimiento como la representación adquieren un espacio fundamental en la medida que permiten concebir las posibilidades de unas identidades en movimiento que, si bien asisten al llamado de una sociedad plural, no desatienden a su mismidad y, por ende, a sus visiones propias del mundo. Ello, sin duda, admite una revisión a las políticas públicas tanto como a las instituciones que -para el caso colombiano- han destacado estos temas como parte de sus prioridades, planes estratégicos y, por qué no mencionarlo, de la sostenibilidad de formas del nombrar desde el silenciamiento apelando presuntamente al plano de la alteridad y la diversidad.

Así es como el presente proyecto acude a la producción visual como un escenario para problematizar sobre las prácticas hegemónicas que subyacen a estas lógicas dominantes que han primado al momento de reconocer la pluralidad desde enfoques diferenciales, comprendiendo la fotografía como una acción política que manifiesta mecanismos de resistencia social y, desde luego, permite establecer diálogos de reciprocidad con los sentidos y percepciones respecto a la representación que surgen en comunidades históricamente invisibilizadas.

A razón de lo anterior y considerando la relevancia de realizar contribuciones críticas a las discusiones tanto en ámbitos teóricos como prácticos sobre los vínculos y oposiciones entre las prácticas culturales e identitarias y los medios de comunicación e información, la investigación en referencia, procura trazar un camino para fortalecer experiencias asociadas con encuentros colaborativos con comunidades desde una mirada distante de lo instrumental-objetual que concibe los grupos sociales como "sujetos proporcionadores de información", resaltando un carácter extractivista del investigador clásico y excluyendo toda opción de una investigación como intercambio de conocimientos; intercambio que fundamenta el desarrollo de este proyecto. Con estas formulaciones expuestas, se presenta a continuación el problema que fundamenta este proceso investigativo: 


\section{PROBLEMA DE INVESTIGACIÓN}

\section{- Eje problémico}

La pregunta problema que direcciona el presente proyecto de investigación refiere a lo siguiente:

¿De qué manera es posible evidenciar prácticas identitarias y de reconocimiento a través de la intervención de los medios de comunicación en el Cabildo indígena Nasa de

Bogotá, Colombia? 


\subsection{OBJETIVOS}

\subsubsection{Objetivo general}

- Analizar la configuración del reconocimiento en la comunidad indígena Nasa y su relación con el discurso de los medios de comunicación tradicionales y masivos, a partir de los relatos de vida de 3 sujetos pertenecientes al Cabildo Indígena Nasa de Bogotá, Colombia.

\subsubsection{Objetivos especificos}

- Caracterizar las prácticas y significados que los integrantes del Cabildo Indígena Nasa de Bogotá, Colombia otorgan al reconocimiento y menosprecio a través de sus relatos de vida.

- Identificar el lugar de los medios de comunicación en la configuración de prácticas de reconocimiento en la comunidad indígena Nasa para la caracterización de sus experiencias de interacción mediática.

- Generar un portafolio fotográfico evidenciando las condiciones del Cabildo Indígena Nasa de Bogotá, Colombia a través de sus prácticas identitarias y percepciones frente a la incidencia de los medios de comunicación en sus modos de reconocimiento como comunidad indígena. 


\subsection{ANTECEDENTES}

A modo de establecer claridades tanto del tema como del problema de investigación ya enunciado, así como de analizar críticamente algunas experiencias de trabajo con comunidades indígenas aunado a contextos comunicativos, a continuación, se presentan dos ámbitos de la cuestión a saber: perspectivas sobre el estado de las comunidades indígenas en Bogotá y los diálogos y divergencias en medios de comunicación nacionales frente a las prácticas identitarias de los grupos indígenas tanto a nivel distrital como nacional.

Lo anterior considerando la importancia de un estado del arte que cimiente las formulaciones del problema de investigación a abordar y, a su vez, que no desatienda a la coyuntura socio política propia del conflicto armado colombiano, la cual ha incidido notoriamente en prácticas de desarraigo y estigmatización de poblaciones migrantes indígenas y en el asentamiento de las mismas en escenarios urbanos como las grandes capitales del país.

\subsubsection{Perspectivas sobre el estado de comunidades indígenas en Bogotá}

Caminar por las calles de las principales calles o avenidas de Bogotá en un día común, no solo es aventurarse al descubrimiento de espacios monumentales, encontrarse con la calidez de sus habitantes y con multitud de estímulos visuales y sonoros que van y vienen sin cesar buscando atentos espectadores y curiosos. Caminar por algunos tramos de la ciudad, también permite entrever las condiciones de abandono y vulnerabilidad a las cuales se ven expuestas diferentes grupos étnicos que, aún sin distinguir en su totalidad una enorme ciudad que jamás se detiene, han posicionado formas auténticas de territorializar los espacios de la ciudad y constituido sus propias formas de habitar a partir de lo que podríamos llamar como la supervivencia en contextos de paradójica hostilidad.

Según el informe Bogotá Indígena (2018), una experiencia colectiva e intercultural realizada por periodistas pertenecientes o no a grupos indígenas, más de 37 mil indígenas habitan la capital del país. Grupos étnicos entre los que se encuentran Misak, Nasa, Pijao, Emberá y Muiscas, entre otros. Esta es una cifra que, aunque parece compleja de precisar por localidades dada la constante movilidad de familias en busca de viviendas más dignas, hay registros del año 2005 de la secretaría Distrital de Planeación donde se presenta que la mayor concentración 
de comunidades étnicas en Bogotá se encuentra en sectores como Suba, Bosa, Engativá, Kennedy y Ciudad Bolívar; esta última donde -a tal fecha- se encontraría más del $60 \%$ de la población.

No obstante, a las variabilidades estadísticas se suman asuntos como el autoreconocimiento, pues en algunos casos, muchos habitantes de estas localidades no se reconocen como grupo étnico particular ${ }^{4}$. Lo anterior, determina la inexistencia de cifras concretas que den cuenta del estado actual de permanencia de estas poblaciones en la ciudad.

Este aspecto destaca en los Resultados del Censo Nacional de Población y Vivienda 2018 (2019), donde se encuentra que los procesos de medición estadística de asentamientos indígenas tanto a nivel nacional como distrital están asociados al enfoque diferencial de atención desde el cual se aborda a partir del formulario censal hecho tanto por indígenas como no indígenas vinculados al proceso, preguntas que permitan dilucidar la realidad social y demográfica a través de la información que arrojan las estadísticas.

A partir de lo anterior, este documento hace énfasis en la variable de autoreconocimiento como: "sentido de pertenencia que expresa una persona frente a un colectivo de acuerdo con su identidad y formas de interactuar en y con el mundo" (DANE, 2019, p. 7). En ese orden, los resultados arrojan que, respecto al Censo realizado en el año 2005, la población indígena a nivel nacional ha incrementado en un $36.8 \%$ lo cual, siguiendo el informe de resultados, varía por dos factores:

El primero relacionado con el aumento del autoreconocimiento étnico indígena, lo que quiere decir que, a mayor cantidad de habitantes que sostengan identificación con una comunidad étnica, mayor índice de asentamientos humanos. Por su parte, el segundo factor está asociado con la mejor cobertura en territorios con predominancia indígena. En otras palabras, una mayor atención por parte de las entidades encargadas del monitoreo y control territorial; aspecto que resulta ser muy paradójico con las realidades de invisibilización y desatención por parte del gobierno nacional que, aunque destaquen a través del discurso la pluralidad y las prácticas de salvaguarda de la identidad cultural, parece rezagarse a la legitimación de la política pública.

\footnotetext{
${ }^{4}$ Sobre la cuestión del reconocimiento y autoreconocimiento de grupos indígenas, en especial lo que respecta al Cabildo Nasa en Bogotá, se hará referencia en la sistematización de la experiencia investigativa del presente documento.
} 
Al respecto, el decreto 543 de 2011, reglamenta la adopción de una política pública exclusiva para grupos indígenas en la ciudad de Bogotá, según la cual: "El Estado reconoce y protege la diversidad étnica y cultural colombiana" agregando que bajo la Ley 21 de 1991, es deber del Estado garantizar la soberanía de los pueblos indígenas en términos de decisiones propias que contribuyan a su desarrollo económico, social y cultural. Bajo esta directriz, el decreto enfatiza en la protección y salvaguarda de los territorios y sus comunidades atendiendo a la necesidad de los pueblos por el restablecimiento de sus derechos en el marco del desplazamiento forzado producto del conflicto armado interno.

En efecto, el Estado colombiano se compromete a no solo garantizar espacios de deliberación y participación como parte del ejercicio de la ciudadanía sino a generar condiciones dignas para el reconocimiento y sostenibilidad de sus saberes, prácticas y expresiones culturales propias de su cosmovisión y pensamiento ancestral en un marco de equidad

con el fin que tengan las mismas oportunidades y puedan acceder y utilizar los servicios sociales y culturales que aporten de manera positiva al mejoramiento de sus condiciones de vida, en relación con el resto de la población Distrital y entre ellos mismos, de acuerdo con sus necesidades específicas; lo cual incluye el ejercicio de los derechos humanos fundamentales y de los derechos étnicos especiales de autonomía, identidad, participación, territorialidad y desarrollo propio. El ejercicio de estos derechos implica el reconocimiento de su propia concepción de bienestar y plan de vida. (Art. 5)

Consideraciones que, se encuentran plenamente claras en la legislación pero que difícilmente se conducen a su aplicabilidad, pues como menciona el Alto Comisionado de las Naciones Unidas para los Refugiados - ACNUR (s.f), la situación de afectación a las comunidades indígenas continúa siendo crítica debido a las amenazas a la supervivencia física y cultural de estos pueblos en el país.

Ello da lugar a destacar las serias condiciones de vulnerabilidad de estas poblaciones identitarias y migrantes que, siguiendo al Alto Comisionado de las Naciones Unidas para los Refugiados - ACNUR (s.f), no solamente están determinadas por el fenómeno del desplazamiento forzado sino a causas más de fondo como las disputas territoriales entre grupos armados al margen de la ley, el reclutamiento, la instauración de minas antipersona, los asesinatos selectivos, la invasión de sus territorios, la sustitución de los mismos por cultivos ilícitos y la explotación de sus territorios ancestrales por recursos como la minería y los hidrocarburos. 
Una vez los grupos indígenas han recorrido miles de kilómetros buscando condiciones más optimas y seguras para vivir tras las huellas indelebles que ha dejado el conflicto armado en su plan de vida, se enfrentan a otras problemáticas como la precarización a la accesibilidad laboral, la estigmatización social y, en casos más graves, la extrema pobreza y la explotación sexual. En otros casos, también sobresale el menosprecio de su tradición lingüística ancestral que es obligada a desplazarse a la comunicación interna entre grupos minoritarios por la presencia permanente del español.

Ante la complejidad de este panorama, diversos grupos indígenas arriban a la ciudad procurando gestar nuevas prácticas de territorialización en entornos que, aunque pareciese que les son ajenos, históricamente les pertenecen, pues donde ahora se levanta una urbe, antes se mantenía el pensamiento ancestral muisca y la gobernabilidad de los Zipas ${ }^{5}$. Sin embargo, los grupos indígenas que enfrentan estas situaciones adversas en la ciudad no desatienden a sus conocimientos ancestrales como una necesidad vital que, con la llegada a la capital, se transforman en posibilidades de protección y permanencia de su identidad y, de igual manera, de supervivencia.

Al respecto, son sugerentes los planteamientos de la Secretaría de Cultura, Recreación y Deporte (2015) en su Línea de Base - Plan de Acción 2015-2020, donde mencionan lo siguiente:

La mayor parte de su población, valiéndose del conocimiento ancestral y las tradiciones culturales se insertan en el proceso productivo para sobrevivir, especialmente en la producción de tejidos, prestación del servicio de medicina natural, la venta de alimentos típicos y de mochilas, aun cuando recurren a la economía del rebusque, y del comercio informal. (p. 13)

En consecuencia y a lo que refiere el caso puntual de Bogotá, podría afirmarse que comúnmente las zonas de agrupamiento de indígenas que dan a conocer a los ciudadanos su trabajo manual con miras a la generación de ingresos se concentran en sectores como el centro de la ciudad caracterizados por la constante afluencia de residentes, población flotante que trabaja en dichos sectores y extranjeros que se encuentran de paso por la capital del país.

El centro de la ciudad comprende mayoritariamente localidades como Santa Fe y La Candelaria donde la suma de población indígenas asciende a los 706 y 284 seguidamente (Secretaría de Cultura, Recreación y Deporte, 2015). Ello considerando los factores de variabilidad estadística

\footnotetext{
${ }^{5}$ Título de nobleza otorgado al gobernante supremo de la organización Muisca.
} 
mencionados con anterioridad. Y es precisamente en este sector de la ciudad donde está ubicada una de las Casas de Pensamiento Intercultural que, para esta investigación en particular, son supremamente relevantes al ser un espacio de autonomía y que otorga primacía a la educación indígena y la construcción de proyectos socio culturales con enfoque diferencial.

Según datos de la Secretaría de Integración Social (2018), a la fecha la capital colombiana cuenta con diez Casas de Pensamiento Intercultural con capacidad de atención a 1.052 niños ubicadas en 9 localidades: Fontibón, Engativá, Suba, San Cristóbal, Santafé, Kennedy, Bosa, Los Mártires y Usme. Esos espacios diseñados por y para la salvaguarda de las tradiciones indígenas en Bogotá, cuentan con un entorno pacífico y libre de violencias para que especialmente la infancia en condición de vulnerabilidad que llega a la ciudad víctima del desplazamiento forzado tenga un espacio para desarrollar y construir su identidad como sujeto étnico conforme al pensamiento de sus ancestros que le permita no desvincularse de su territorio y su cultura.

De manera que, en la ciudad también es posible encontrar espacios destinados para el fortalecimiento de la identidad indígena, aunque la realidad que enfrentan diariamente resulte ser de gran complejidad, pues la concentración demográfica en la capital permite concebir la presencia indígena a partir de tres aristas o clasificaciones. Investigaciones como la de Molina (2007), apuntan a un entramado poblacional donde pueden distinguirse los indígenas citadinos que tienen sus raíces y orígenes en Bogotá, los migrantes que llegan a la ciudad en busca de mejores condiciones de vida entre los cuales destacan las etnias Kichwa, Inga, Kamentzá, Wayuu, Guambiano, Nasa, Uitoto y Cofán.

Finalmente, se encuentra la clasificación de grupos desplazados como los Pijao quienes llegan principalmente a la ciudad por efectos del conflicto armado. Lo anterior sin desconocer que, en los otros casos, la probabilidad de la causa de la migración a la capital haya sido la misma o asociada a factores de violencia.

Al respecto, autoras como Giraldo (2019), asumen un enfoque desde la sociología relacional para analizar críticamente la coexistencia de comunidades étnicas en la ciudad como la política pública que los acoge. En esta investigación, Giraldo (2019), enuncia que la historicidad de prácticas de exclusión, menosprecio y marginalidad de los grupos indígenas que arriban a Bogotá, determina un problema estructural en la medida que no es solo una cuestión alusiva al imaginario colectivo de muchos ciudadanos y a la percepción que poseen sobre estos asentamientos, sino a los drásticos procesos de modernización y occidentalización que 
demarcan reiteradamente un pensamiento colonial que supone la dominación cultural y la legitima socialmente como tal.

Desde esta perspectiva, Giraldo (2019), expone desde la sociología la relevancia de identificar y profundizar en las condiciones de vulnerabilidad de estas comunidades aquello que, sin lugar a duda, también conduce a analizar crítica y colectivamente las prácticas afirmativas y de estigmatización que se desligan de los discursos que se mantienen imperantes en el imaginario del ciudadano de a pie que también habita la ciudad.

A partir de esto, resulta importante destacar en este estado del arte de la cuestión, algunas experiencias o producciones investigativas que han indagado respecto a estos discursos en el plano de lo social y que están relacionados con percepciones referentes a la condición indígena en contextos urbanos materializadas en materiales audiovisuales y medios de difusión como la prensa y los canales de televisión nacional.

\subsubsection{Diálogos y divergencias entre medios de comunicación y prácticas identitarias de los} grupos indígenas en Colombia

Sanabria (2017) en su ponencia "Representaciones y autorrepresentaciones indígenas en los medios de comunicación", aborda un estudio selectivo a partir de medios de prensa nacional como El Tiempo, El Espectador y Semana para determinar y reflexionar los contenidos informativos que referencian el ser indígena para los medios de comunicación masiva. En ese orden, enfatiza en cuatro categorías: territorio, identidad, comunicación y medios.

Siguiendo estas cuatro categorías, Sanabria (2017), destaca que para el caso de los medios, existe una fuerte influencia de estos en el pensamiento de la modernidad y el proyecto ilustrado, de forma que, tanto la cultura como la comunicación sostienen diálogos frecuentes que no desatienden a la "aprehensión de algo implícito incorporado a grupos vulnerados que, por razones nombradas anteriormente, han sido desplazados, invadidos, o desaparecidos por lo que el imaginario que se tiene deja de lado las tradiciones y la cultura indígena”. (p. 6)

Estas consideraciones se suman a los planteamientos de Morales (2011), desde el ámbito de la comunicación donde concibe el lugar de los medios de comunicación en los procesos de resistencia indígena. En su investigación destaca el caso de Kankuama TV como estrategia de 
fortalecimiento de la identidad ancestral de la etnia Kankuama ubicada en la Sierra Nevada de Santa Marta.

Morales (2011), afirma que "los medios de comunicación tradicionales dramatizan o espectacularizan los conflictos indígenas dejando de lado la complejidad y trasfondo de los procesos" (p. 152), lo que conduce a considerar cómo la historia oficial coopta las dinámicas sociales internas de los resguardos exotizando sus conocimientos ancestrales hasta generar posicionamientos casi que ficcionales frente a las realidades étnicas. En efecto, Morales (2011), establece una distinción entre medios oficiales de comunicación y medios alternativos enunciando que:

Todo aquel medio de comunicación que no se encuentra en la dinámica de lo comercial, ha sido denominado medios alternativos, participativos, comunitarios, ciudadanos, radicales, entre otras denominaciones, pero que tienen en común la pretensión de incidir en el desarrollo social y la apropiación por parte de las comunidades través de los cuales se expresan, representan y visibilizan. (p. 153)

En consecuencia, contemplando que los medios alternativos -siguiendo a Morales (2011)contribuyen a la realización de procesos de resistencia social y a la reflexión sobre el devenir propio de la preservación de la cultura ancestral, surge Kankuama TV, una iniciativa movilizada por la comunidad étnica de los Kankuamos que tiene sus orígenes en una emisora de radio pública gestionada por el Estado. A partir de allí, el grupo indígena contribuye a la emisión del primer canal de televisión con enfoque étnico como posibilidad de reconstrucción de su autonomía y participación en la sociedad.

De allí, Kankuama TV constituye un proyecto que, desde sus inicios, propende por el autoreconocimiento y autorepresentación de los Kankuamos a través de producciones audiovisuales que les son propias y están ambientadas con música tradicional y elementos simbólicos que reivindican tanto la identidad cultural como la memoria ancestral y colectiva.

En paralelo a la investigación de Morales (2011), se sitúan planteamientos de interés como los desarrollados en las Memorias del Encuentro de Escuelas y Procesos de Formación en Comunicación Indígena organizado en Colombia, Valle del Cauca (2017). En las disertaciones sobre "Los medios apropiados como herramientas para la comunicación de lo propio", destaca una vez más el lugar de los medios de difusión en las comunidades étnicas. Sin embargo, se 
hace referencia al plano radial que, según se afirma en este abordaje investigativo, se vinculó a las poblaciones ancestrales a mediados de los años 2001-2002.

Con el lugar que secuencialmente adquieren las emisoras en ciertos grupos, empiezan a madurar iniciativas como Radio Payumat propia de los cabildos del pueblo Nasa ubicados en Cauca donde se han aunado esfuerzos por recuperar la tradición lingüística Nasa Yuwe.

Sin duda, las prácticas de apropiación y resignificación de los medios de comunicación en los grupos indígenas contribuyen de forma muy potente a gestar procesos de interculturalidad potenciando a su vez lazos de hermandad y respeto a la diversidad dentro y fuera de los resguardos.

Del mismo modo, el empoderamiento cobra gran relevancia dada las posibilidades de agenciar discursos propios y revitalizar la memoria como pueblos originarios. En esta medida, son los discursos tanto como la memoria los detonantes para fortalecer la producción y diversificación de narrativas auténticas. Al respecto, estas memorias recogen la experiencia de comunicación del pueblo Wayuu, agregando que:

Cada experiencia comunicativa se encuentra en la búsqueda de identificar la naturaleza de la narración de sus propios relatos, sus ritmos y tiempos. La escuela de comunicaciones del pueblo Wayuu en el departamento de La Guajira le llama herramienta comunicativa a los géneros periodísticos, es decir al reportaje, noticia, entrevista y crónica como estrategia para que los jóvenes aprendices tengan un referente de cómo contar sus historias. A los jóvenes no se les brinda una clase técnica de planos, encuadres o composición, ni tampoco de cómo manejar la cámara. Solamente se les enseña dónde se prende, dónde se apaga y cómo se graba y después se van a contar una historia. Los referentes brindados, la identificación de la historia y su grabación se desarrollan en día y medio. (2017, p. 90)

Y así como en latitudes como La Guajira tan distantes geográficamente de la ciudad de Bogotá se tejen prácticas de resistencia y comunicación a partir de los medios y la construcción identitaria a través de las narrativas, en otros escenarios a lo largo del país, se gestan prácticas de encuentro e incluso de desencuentro entre la cosmovisión indígena y el pensamiento occidental propio de los discursos que subyacen a medios de comunicación como la televisión nacional donde el reconocimiento de las comunidades indígenas termina concluyendo en una exploración inadmisible de "conquistadores que traen consigo un conocimiento que será 
impartido a quienes carecen de él”; posicionamientos que perpetúan la estigmatización y el menosprecio a las prácticas del sentir y pensar propias del devenir indígena.

A esto último apuntan investigaciones como la de Salazar (2018) que trae a discusión las movilizaciones sociales de las comunidades indígenas del pueblo Nasa en Huila y Cauca donde según el autor, la intromisión de formas hegemónicas del discurso en el plano de la información, tergiversan los hechos reproduciendo una voz que como se mencionaba páginas atrás, constituye una voz réplica de una historia oficial.

De acuerdo con Salazar (2018), las experiencias de convergencia entre grupos indígenas y medios de comunicación son totalmente infortunadas y desacertadas dada la injerencia de fuentes de control y dominación. En efecto, se ejerce un discurso nacional ideológico que determina aquello que es comunicado y aquello que no lo es. El investigador toma como eje de análisis el manejo informativo y enfoque de medios digitales de comunicación colombianos como El Tiempo, Revista Semana, El Espectador, Caracol, RCN y medios locales del Huila frente a los procesos de movilización indígena registrados entre 2008 y 2013 en los departamentos de Cauca y Huila.

Salazar (2018) afirma que esta tergiversación comunicativa se debe principalmente a la pertenencia de los medios por parte de grupos empresariales quienes ejercen a través del dominio modos de agresión y victimización a los indígenas que integran la Minga Nacional de Resistencia Indígena y Popular. Así las cosas, continuando los postulados de Salazar (2018), la labor de los medios de comunicación que cubrían los hechos acontecidos en este marco refiere a:

La voz oficial que los medios reprodujeron como propaganda fue la de no permitir la vía de hecho y el taponamiento de las carreteras, así justificó mediáticamente el uso de la fuerza para desmovilizar. Los medios le hicieron juego al intento errático del gobierno por reducir a dilema de orden público el grave problema social. También, se demostró que el cubrimiento fue coyuntural a la acción de intervención violenta del ESMAD $^{6}$ para despejar la vía Panamericana. Es decir que el cubrimiento informativo se ocupó mediáticamente en el momento del bloqueo y la presunta respuesta violenta

\footnotetext{
${ }^{6}$ Escuadrón Móvil Antidisturbios. Es una unidad especial adscrita a la Policía Nacional de Colombia que tiene por objeto disuadir a la ciudadanía y disolver las alteraciones del orden público con fines de restablecimiento del orden (disolución que históricamente se ha convertido en una amenaza letal para quienes ejercen su derecho a la protesta social).
} 
de los indígenas frente a la presencia policial para mantener la seguridad y el orden en la zona. (p. 13)

En efecto, para esta experiencia en particular, los medios de comunicación no acentúan en los diálogos y procesos de salvaguarda de las culturas indígenas como en casos anteriormente mostrados sino apuestan por discursos de estigmatización que representan una inferioridad del ser indígena frente a los procesos de resistencia social que adquieren mayor fuerza dadas las estrategias del Estado para crear informaciones confusas desviando los propósitos fundantes de la movilización indígena.

De forma tal que: "ante esta diversidad, resulta llamativo que el discurso de los medios de comunicación suela seguir enriqueciendo un imaginario con visiones simplistas y antagónicas que enfrentan tradicional versus moderno, barbarie versus civilización o retraso versus progreso" (Franco, 2017, p. 2). Pues, por más políticas públicas y estrategias existentes para la consecución de una comprensión amplia sobre la diversidad, se mantiene inmanente una tradición colonial desde la cual los medios de comunicación que ejercen poderes casi que totalitarios frente a la información que se consume e interpreta por parte de los espectadores, reproducen formas del nombrar discriminatorias y de subordinación que nada tienen que ver con los principios de alteridad sobre los cuales se encuentra cimentado el enfoque diferencial donde aunque la heterogeneidad esté presente, las relaciones de pertenencia entre "ellos" y "otros" se quebrantan para dar lugar a un "nosotros"; un lugar de enunciación que enmarca los el abordaje teórico del proyecto de investigación y que se describirá a continuación: 


\section{MARCO TEÓRICO}

La presente investigación concibe el lugar de enunciación del devenir indígena como uno de los aspectos fundamentales al momento de no solo desarrollar la praxis investigativa sino de interrogar críticamente los contextos que subyacen a la intervención y posicionamiento de los medios de comunicación en las prácticas ancestrales, étnicas y comunitarias.

Considerando lo anterior, los referentes conceptuales y creativos que sustentan este abordaje investigativo se componen inicialmente de una mirada a las nociones de reconocimiento y representación que enmarcan el eje problémico, así como su lugar en la cultura e identidad de las comunidades indígenas. Seguidamente, se desarrollan una serie de precisiones respecto a las subcategorías que fundamentan los relatos a presentar en el componente de trabajo de campo.

Posterior a ello, se realiza un acercamiento a la relación entre medios de comunicación y grupos indígenas enfatizando en investigaciones que contribuyen a reforzar dichos modos hegemónicos de representación de los cuales se ha hecho mención en el apartado de antecedentes.

Finalmente, se construye una disertación acerca de tres aspectos esenciales a saber: una contextualización frente a las dicotomías emergentes entre el habitar la ruralidad y el espacio urbano a la luz de las experiencias propias de la comunidad indígena Nasa en el país, al igual que la postura estética y periodística que compone el presente proyecto en términos de la producción fotográfica como apuesta ética y política por el reconocimiento del grupo indígena en mención.

3.1. Del reconocimiento y la representación de las prácticas identitarias y culturales de las comunidades indígenas en Colombia

Un abordaje a la noción de reconocimiento como una suerte de epicentro de la conflictividad social, puede rastrearse a partir de las trayectorias de la teoría crítica en autores como Honneth (1997) quien, considerando la perspectiva hegeliana sobre las relaciones sociales, plantea que: "la pretensión de los individuos a un reconocimiento intersubjetivo de su identidad es la que, desde el principio, como tensión moral, se aloja en la vida social” (p. 13). Ello, permite 
dilucidar que, a la luz de Honneth (1997), hablar de la existencia y legitimación de un reconocimiento implica, en efecto, la distinción de relaciones entre pares y, por supuesto, los constructos identitarios, sociales y culturales que subyacen a dicha relación.

En ese orden de ideas, el reconocimiento devela una lógica moral de los conflictos sociales que, siguiendo la tradición epistemológica del autor, permite examinar entre líneas las prácticas hegemónicas que se han instaurado como parte de la vida en sociedad y que son resultantes de las huellas que ha dejado el capitalismo sobre la distinción de clases.

Así pues, el reconocimiento está mediado por las 3 esferas sociales e instituciones por excelencia: la familia, la sociedad civil y el Estado. De allí que, siguiendo a Honneth (1997) y como se detallará en el apartado siguiente, a cada una de estas instancias se le atribuye una forma de reconocimiento distinta.

Pensado de esta forma, el reconocimiento como develamiento de las luchas sociales, propicia una mirada políticamente radical a grupos declarados como marginados y secundarizados parte de ese entramado sistémico propio de los ideales del capital. En este sentido, el reconocimiento honnethiano analiza aquellos mecanismos que dan lugar a formas de exclusión y silenciamiento resultantes de la sociedad de contrastes y separaciones.

Para el caso en referencia, dichas formas de exclusión están determinadas por los discursos mediáticos y, en efecto, por las restricciones a la libertad de acción cuando estos discursos se asientan con fuerza desmedida en el plano de la información.

Por supuesto, esta noción de reconocimiento se fundamenta en la visibilización de las luchas en contextos y movimientos sociales. De allí que, aunado a la propuesta de Honneth (1997), los movimientos sociales son hijos de la resistencia que propicia dos aristas del reconocimiento: por un lado, la existencia de coyunturas particulares -un caso podría ser las luchas por la reivindicación a manos de las comunidades indígenas en Colombia-, que termina siendo un foco de interés por parte de ciertos medios que distorsionan dichas realidades y, por otro lado, tal presunto reconocimiento que se realiza a las comunidades desatendiendo a su lugar como sujetos políticos.

En conclusión y atendiendo a Honneth (1997), toda lucha por el reconocimiento es una lucha por la emancipación y en el camino de lograrla, el disenso construye el terreno de la disputa. Es así como, es inverosímil pensar en el reconocimiento sin la conflictividad y, en 
consecuencia, las significaciones históricas que manifiesta tal reconocimiento y que se detallarán en líneas posteriores.

Al respecto, son sugerentes los planteamientos de Capasso y Bugnone, (2016) que, retomando la idea de Rancière sobre el disenso en la política y en contextos de agenciamiento político, plantean que: "el disenso supone una reconfiguración del orden que determina que no hay lugar para los que no tienen parte, es decir, que impone la negación de la politica, la supresión de la igualdad" (p. 123). De manera que, la existencia del disenso, aunque en ocasiones negativa, resulta relevante para develar las fragmentaciones de las relaciones sociales y, por adición, la heterogeneidad de luchas y resistencias que las sustentan.

Y es precisamente en este plano de luchas y resistencias donde la noción de reconocimiento se encuentra ligada con la de representación -vista desde una perspectiva que trasciende a la puesta en escena o teatralización-, pues si bien la representación en tanto concepto polisémico está tradicionalmente asociada con la imitación o construcción de ficciones, en este caso refiere a un posicionamiento político desde el cual algunos sujetos o esferas sociales se permiten enunciar desde el «otro» y sobre «lo otro»; es decir, la representación se legitima en las formas del discurso y las estrategias retóricas para legitimarlo como verdadero.

Desde este punto de vista, surgen los estereotipos o estigmatizaciones en el nombrar. Así, algunos actores o instituciones continúan instaurando la violencia simbólica en el lenguaje a través de etiquetas lingüísticas comunicadas en sentidos despectivos como "indio" para referirse a indígena o para hacer acotaciones a la ignorancia, analfabetismo, etc., desconociendo los saberes ancestrales de las comunidades y disminuyendo las posibilidades de concebirlos desde sus propias maneras de autorepresentación.

Esto permite pensar que, en el marco de la representación, no solo está en juego la comunicabilidad del discurso sino las implicaciones que ello tiene tanto para las comunidades a las que apunta como para todos aquellos que interiorizan su contenido. De forma tal que, al tiempo, emerge una suerte de "apisonamiento cultural" (Shohat y Stam, 2002) que suprime las posibilidades de la diferencia; en otras palabras, hay una normalización de las formas violentas al enunciar por «otros» aquello que podría concebirse desde ellos mismos, ubicando en la cumbre de una estructura piramidal las voces de quienes tienen en sus manos el poder de representar y bajo ellas, las voces de quienes son representados. 
A razón de lo anterior, tanto en el reconocimiento como en la representación sobresale la figura de la ideología donde, siguiendo a Shohat y Stam (2002), la idea del reflejo y la mimesis toma preponderancia para dar una visión sobre la realidad. Por ello, la representación -pensada desde la posibilidad comunicativa- posee múltiples connotaciones que, siguiendo a los autores, van desde lo religioso, estético, político, hasta lo semiótico, pues en todos los casos, existe una narrativa configurada con intenciones bien de dominación, ocultamiento, rechazo u opresión orquestada desde aquellos situados en la punta del iceberg.

De allí que las jerarquías de poder que subrayan estas dos nociones en el campo de las prácticas culturales, no solo alimentan dichos intereses sino que demarcan la emergencia de unas acciones afirmativas o consentimientos positivos que, aunados a la idea de Honneth (1997) sobre la cortina de humo que establecen los medios para "dar por hecho" procesos de alteridad, reconocimiento de la diferencia, etc., concluyen en situaciones como la presunta preocupación por los acontecimientos de gran peso sociopolítico cuando bajo tales presunciones se abren nuevas fisuras para "ganar la partida" en esta pugna permanente por el posicionamiento social y los lugares de enunciación; por la verosimilitud de un retrato de la vida en colectivo.

En consonancia con lo anteriormente expuesto, resultan adecuadas las afirmaciones de Fraser (s.f) acerca de las dos dimensiones que componen la justicia: redistribución y reconocimiento. Fraser (s.f), plantea que, por un lado, está el problema de la injusticia socioeconómica ligada al desfavorecimiento social, carencia de recursos y privación de una vida digna y, por otro, una injusticia cultural o simbólica determinada por la dominación cultural y los modos de hostilidad y representación tanto propia como ajena.

En efecto, "lejos de ocupar dos esferas separadas herméticamente, la injusticia económica y la injusticia cultural se encuentran habitualmente imbricadas hasta el punto de reforzarse dialécticamente la una a la otra" (Fraser, s.f, p. 6), de modo que, simultáneamente y con la continuidad de la inequidad en el capital, persiste la cooptación social acentuando un muro divisorio entre los poseedores de la riqueza y los habitantes de la pobreza. Esto, subraya una vez más la subordinación y el pensamiento de binarios al que históricamente hemos estado anclados.

Ante este panorama, la respuesta no está precisamente en el destacamiento y afirmación de la igualdad sino en el reconocimiento y problematización de la diferencia, porque: 
...cualquier injusticia estructural que sufran sus miembros se remitirá en último término a la estructura de valoración cultural. El origen de la injusticia, así como su núcleo, será el reconocimiento inadecuado, mientras que cualquier injusticia relacionada con la economía estará producida, en último término, por su origen cultural. (Fraser, s.f, p. 10)

Así las cosas, tanto la representación como el reconocimiento están imbricados en el constructo social a manos de las instituciones o instancias de poder consentido que hemos legitimado como tal. Desde allí, es posible determinar las formas del reconocimiento (Honneth, 1997) que, sustentan el abordaje a los relatos de vida que componen la presente investigación.

\subsection{Significaciones de reconocimiento y menosprecio. Aproximaciones a sus categorías subyacentes}

Como se mencionó anteriormente, la noción de reconocimiento se encuentra mediada por tres instituciones que, siguiendo algunos postulados de Hegel (citado por Honneth, 1997), acerca de su teoría de los estadios, podría sintetizarse de la siguiente manera:

1. La familia como espacio de formación inicial de los sujetos constituye un contexto de interacción donde se tejen diálogos y relacionamientos a partir de la intersubjetividad. De allí que, aquí el amor toma lugar como categoría subyacente en la medida que en el componente familiar "el espíritu subjetivo no se ve sacudido en principio por conflictos, que le fuercen a reflexionar acerca de normas globales y generales de reglamentación del trato social" (Honneth, 1997, p. 55). Siguiendo al autor, en esta primera institución o estadio, el sujeto aún no ha interiorizado su lugar como portador de derechos y, en efecto, como ser político. Por el contrario, persiste una figura intuitiva de necesidad ligada a lo afectivo donde emergen vínculos de confianza, dependencia y reciprocidad.

2. La sociedad civil como escenario conflictivo donde los sujetos adquieren capacidades cognoscitivas suficientes para concebirse como portadores de derechos; es decir, sujetos políticos. En este plano, se desarrolla la autonomía formal y emerge el derecho como una posibilidad de visibilización de intereses particulares, pues "vivir sin derechos individuales significa, para el miembro de la sociedad, no tener ninguna oportunidad para la formación de su propia autoestima" (Honneth, 1997, p. 147). Desde este punto de vista, podrían enmarcarse las luchas y resistencias de los movimientos sociales que reclaman por equidad y reconocimiento más que como 
ciudadanos, como individuos con agenciamientos propios sobre sus identidades y memorias colectivas.

3. El Estado como garante de derechos y reconocedor de las individualidades que, por su poder institucional requiere fundamentarse en una ética afianzada en el bienestar propio y grupal. Desde allí, destaca la solidaridad como posibilidad para afianzar el reconocimiento social de las subjetividades y colectividades pues, para Honneth (1997), la solidaridad social demanda la construcción y legitimación de valores consentidos para, desde allí, abogar por un reconocimiento como sujeto de derecho y, en consecuencia, como agente colectivo.

Sin embargo, a estas tres instituciones y sus praxis, les corresponde una manifestación de menosprecio que "en la autodescripción de quienes se ven tratados con falsedad por los otros desempeñan hasta hoy un papel predominante categorias morales como «ofensa» o «humillación», que se refieren a formas de menosprecio o de denegación del reconocimiento" (Honneth, 1007, p. 160), formas que, siguiendo al autor, están representadas de la siguiente forma:

1. A la familia se le atribuyen las formas subyacentes de maltrato y violación a la integridad física que, sin duda, reafirman prácticas de humillación y destrucción del autoreconocimiento. Estas manifestaciones de menosprecio en la familia no solo generan afectaciones de orden corporal sino otros efectos como:

... asociación con el sentimiento de estar indefenso frente a la voluntad de otro sujeto hasta el arrebato sensible de la realidad. El maltrato físico de un sujeto representa ese tipo de menosprecio que lesiona la confianza, aprendida en el amor, en la capacidad de la coordinación autónoma del propio cuerpo; por ello, la consecuencia, acompañada de una especie de vergüenza social, es la pérdida de la confianza en sí mismo en el mundo que se extiende hasta las capas corporales del trato práctico con otros. (Honneth, 1997, p. 161-162)

Dado lo anterior, el menosprecio familiar desencadena una pérdida de la autonomía sobre la corporalidad y del dominio de sí. 
2. Para el caso de la sociedad civil, las categorías subyacentes de desposesión de derechos y exclusión social toman lugar cuando no solo se viola la autonomía personal sino se elimina el status que el sujeto ha adquirido en sus relaciones en comunidad. Pues, siguiendo a Honneth (1997):

Significa ser lesionado en sus expectativas de ser reconocido en tanto que sujeto capaz de formación de juicios morales; por eso, la experiencia de la desposesión de derechos va unida a una pérdida de respeto de sí, por consiguiente, de la capacidad de referirse a sí mismo como sujeto de interacción legítimo e igual con los demás. (p. 163)

En efecto, con la desposesión y la exclusión, el sujeto es relegado a una enajenación y negación de aquello que por ley le pertenece o es digno de obtención. Para el caso en referencia, en estas categorías subyace la historicidad de reclamaciones por parte de los pueblos indígenas frente a la incapacidad social de concebir sus prácticas culturales e identitarias, así como sus marcos de legislación ancestral.

3. Finalmente, al Estado refieren la indignidad e injuria que manifiestan deshonra. En este orden, "lo que aquí se le arrebata a la persona en reconocimiento por el menosprecio es la aquiescencia social a una forma de autorrealización que él debe encontrar dificilmente con ayuda del aliento y de las solidaridades de grupo" (Honneth, 1997, p. 164); esto quiere decir que, el sujeto se convierte en el blanco de señalamientos y estigmatizaciones que no le permiten la continuidad de sus procesos de interacción social.

En este punto, el menosprecio adquiere matices de infravaloración cuando se legitiman los discursos de inferioridad relacionados con un rasgo que identifica a un grupo en contraste con otros. Tales relatos lesionan el honor como sujeto y colectividad, así como la percepción social de la dignidad.

En síntesis, en la formación y pugna por el reconocimiento se encuentran tanto aquellos valores que, se espera, se fomenten desde las tres esferas de desenvolvimiento como individuos, así 
como aquellos contrarios que naturalizan el menosprecio como modalidades de abrir las fisuras sobre el terreno construido para posibilitar dicho reconocimiento.

En este orden, tanto las relaciones primarias (familia), como las de derecho (sociedad civil) y de comunidad de valores (Estado), si bien son plenamente imprescindibles para la construcción de la inter y subjetividad, también potencializan dimensiones de la personalidad distintas, así como formas de comprender o silenciar al «otro». A razón de ello, resulta sugerente realizar una aproximación a la configuración de los discursos mediáticos con relación a los grupos indígenas, a la luz de posibles lugares de reconocimiento y menosprecio desde los contenidos audiovisuales.

3.3. Sobre representación y reconocimiento: miradas a la relación entre medios de comunicación y saberes indígenas

La relación medios de comunicación y comunidades indígenas suele presentarse como una suerte de dicotomía que, en consecuencia, afecta principalmente y en sentido negativo a las prácticas de representación y reconocimiento que subyacen al interior de las comunidades y $a$ posteriori en aquellas que se proyectan desde la praxis social.

Desde esta perspectiva, destaca la importancia de realizar un abordaje a la funcionalidad de los medios de comunicación como algo más que modos de creación o visibilización de los contextos, sino como "verdaderas estrategias de agenciamiento político para la defensa de la vida y con un ideal de cambio en los paradigmas civilizatorios de nuestra sociedad" (Mora, 2015, p, 17); aquello que implica, sin lugar a dudas, dar apertura a la concepción de la comunicación audiovisual como herramienta ética y política para el ejercicio de una ciudadanía intercultural.

Siguiendo a Mora (2015), el lugar de la auto y representación ha determinado puntualmente las narrativas de las etnografías visuales, al igual que los productos audiovisuales con perspectiva antropológica. De allí que, según el autor, podría afirmarse que los grupos indígenas empiezan a tener presencia en las pantallas cargando consigo la historicidad de modos de desprecio y rechazo social a los cuales se han visto victimizados por décadas de representación occidental.

Así pues, es solo hasta inicios de los años sesenta que las producciones audiovisuales empiezan a integrar las narrativas y experiencias testimoniales de los indígenas con su propia voz (Mora, 
2015) y, con ello, a develarse la cuantiosa deuda histórica por épocas de violencia física y simbólica hacia las identidades. Sin embargo, este develamiento fue propiciando simultáneamente una tendencia del cine indigenista que, en palabras de Mora (2015): “aunque comprometido con las visiones traumáticas de los pueblos indígenas, mantuvo un "poder semiótico" que monopolizó hegemónicamente las representaciones étnicas por fuera de su propio mundo simbólico" (p. 19), aspecto que demarca una vez más la sobreposición de intereses publicitarios, económicos e incluso político-discursivos frente a las necesidades de reconocimiento de las comunidades indígenas.

En este sentido, sobresale una pugna simbólica entre el posicionamiento de quién dirige la producción audiovisual y quienes -se espera- intervengan en ella y sean sus protagonistas: los indígenas; pugna que, en la mayoría de las ocasiones, concluye en una representación extractivista donde se absorben los saberes ancestrales sin mayores consideraciones frente a su valoración. En efecto, la producción audiovisual supone un ejercicio principalmente éticopolítico donde se pone en juego las identidades tanto como sus interpretaciones.

Por otro lado, se distingue la categoría de activismo social que, si bien constituye una nueva vía para la representación y reconocimiento, acentúa en el plano de lo comunicativo la agitación política, resistencia y la libertad como derechos de las comunidades étnicas. En palabras de Mora (2015):

Los imaginarios de las contraculturas ancestrales han permeado el imaginario de activistas que reciclan, mezclan y crean imágenes, sonidos y textos provenientes del mundo indígena. Estos activistas de distinta proveniencia -de agencias no gubernamentales de derechos humanos o de defensa de los derechos indígenas, de movimientos antiglobales o de las propias organizaciones indígenas-producen un tipo de material que usualmente permanece al margen de la esfera "pseudopública" de los grandes medios (cine, televisión y DVD masivos), justamente porque conciben su praxis como una "guerrilla cultural electrónica" que reacciona al orden dominante, es decir, a los modelos políticos, culturales y económicos del capitalismo transnacional. (p. 21)

Al ser más "flexibles" en su difusión y más sucintas en su contenido, estas plataformas alternativas de comunicación como activismo permiten considerar una especie de lectura a 
contrapelo que, incluso, llega a alcanzar mayor poder reivindicativo que los mismos artefactos discursivos tradicionales (noticieros, prensa, etc.). Sin embargo, independiente de su alcance, epistemologías como la decolonialidad, convocan a una mirada de las producciones audiovisuales como posibilidades «otras» de interlocución con lo «otro» donde se resalta la herida colonial en las comunidades étnicas propendiendo por la ruptura y desjerarquización de fronteras del conocimiento. Esto último, conduce a formular el conocimiento ancestral y sensible como saber legítimo, no opositor y heterogéneo frente al occidental.

Y son precisamente estas fisuras que ameritan ser leídas y conceptualizadas las que fundamentan los principios de una no tan lejana Política Pública de Comunicación Propia de los Pueblos Indígenas de Colombia (2014), en la cual se sugiere reconocer dicha herida colonial con el fin de reconocer el lugar de las comunidades étnicas en la consolidación del Estado pluriverso.

En continuidad con esta Política Pública (2014), se propone generar acciones alcanzables para detener las afectaciones e impactos negativos de los medios masivos de comunicación y del mismo Estado a los procesos indígenas, así como permitir la superación de olas de violencia representadas en el reconocimiento negativo a manos de la discriminación, la desinformación y la violación de derechos fundamentales, entre otros. Dado lo anterior, destaca el enfoque decolonial pensado desde la interculturalidad donde los ideales de cultura dominante y subalternas no inciden en las prácticas de reconocimiento, reafirmación y representación.

En este orden de ideas, la comunicación indígena no amerita pensarse desde una perspectiva hegemónica sino como:

... una garantía para el ejercicio integro de los derechos fundamentales de los pueblos indígenas; está íntimamente ligada a las estructuras de transmisión y conservación de la cultura, y se constituye en su principal soporte. Por eso, las estrategias de la comunicación indígena son fundamentales en los procesos de fortalecimiento y revitalización de las lenguas propias, en el desarrollo de las garantías de acceso, conservación y preservación de los espacios y sitios sagrados y especialmente en la defensa del territorio ancestral, que está íntimamente ligada y hace parte de él. (ONIC y MinTIC, 2014, p. 18) 
Aquello que admite pensar en la relevancia de los medios de comunicación como herramientas de diálogo y preservación de la cosmovisión indígena donde la palabra adquiere mayor potencia que las imágenes dado el carácter de la oralidad como instancia de interlocución con la naturaleza y consigo mismo. En consecuencia, una política pública precisada en contextos de comunicación es totalmente relevante para el resarcimiento del etnocidio lingüístico y cultural al cual han sido sometidas las comunidades, así como para generar un equilibrio social en términos de equidad comunitaria y relacional; lo que quiere decir que tanto las comunidades indígenas como no indígenas puedan acceder a las estrategias comunicativas como mecanismos de fortalecimiento de su cultura.

\subsection{Acercamientos a los lugares de enunciación en el devenir indígena Nasa}

Considerando entonces esta primacía de abordar las voces y sentires de las subjetividades indígenas, resulta importante enunciar que, aunque -en términos tradicionales- un marco teórico se encuentre pensado desde la teorización y la aplicabilidad posterior de postulados, el presente proyecto se fundamenta en una práctica investigativa que, aunque concibe los aportes desde distintas epistemologías y abordajes conceptuales, también debe su accionar a los posicionamientos o lugares del nombrar del cabildo Nasa ubicado en la ciudad de Bogotá, Colombia.

Sin embargo, y teniendo presente la coyuntura en curso resultante de la emergencia sanitaria por el COVID-19, este apartado relaciona algunas voces de líderes e integrantes de la comunidad indígena Nasa asentada en distintas partes del país a través del recurso audiovisual como punto de partida para trazar puentes entre fundamentos de corte teórico enunciados con antelación y epistemologías «otras» como formas de comprender desde el conocimiento situado aproximaciones al reconocimiento indígena desde algunas intervenciones en medios de comunicación.

En lo que refiere al documental "Nación Indígena" dirigido por Antonio Morales, es posible encontrar un abordaje a la comunidad indígena Nasa del departamento del Cauca donde destaca la idea de una relación entre medios de comunicación audiovisual y grupos autóctonos plenamente mediada por la visibilización que los mismos integrantes de la comunidad realizan de sus prácticas identitarias. Desde allí, es posible mencionar cómo algunos líderes indígenas 
como es el caso de María Ovidia, afirman en el documental su afirmación propia sobre quiénes son, agregando que:

...los pueblos originarios nunca han tenido límites. los pueblos originarios han sido eso, del ir y del venir -como diría un mayor Yanacona-. Quiere decir que no estamos en un solo lado, ni que somos delimitados sino vamos y venimos, que tenemos una relación reciproca con la tierra, con el territorio porque es que el territorio es vida, el territorio no solamente está el ser humano sino todos aquellos hermanos mayores: el sol, la luna, la tierra, el agua, las montañas, los cerros... (Extracto de intervención de María Ovidia, líder indígena Nasa en documental "Nación Indígena").

Estas palabras acentúan aquello que en apartados posteriores se relacionará con los modos de reconocimiento en integrantes del cabildo Nasa de Bogotá. No obstante, las palabras de María Ovidia como de otros indígenas pertenecientes a esta comunidad y expresadas en el documental, evidencian la importancia de reflexionar en la conformación de un grupo identitario concebido como nación en sí misma, antes de abordar los modos de auto y reconocimiento en función de los medios de comunicación.

Lo anterior, considerando que la concepción de nación indígena más que como grupos étnicos pertenecientes y partícipes de un Estado, está ligada a la preponderancia que los Nasa otorgan al territorio principalmente asociado a la ruralidad. De allí sobresale la tensión de las prácticas de movilización de los asentamientos rurales a los sectores urbanos, aquello que, en paralelo, transforma radicalmente la noción de territorio y las amplitudes de una nación indígena que ya no solo está asociada a un espacio físico sino a unas formas de pensamiento en función de estos tránsitos. Así pues: "la nación es la cosmovisión práctica y viva del hacer político de los pueblos" (Extracto de intervención de Feliciano Valencia, líder indígena Nasa en documental "Nación Indígena").

En efecto, persiste una lucha constante no solo por el restablecimiento de derechos sino por la constitución como nación indígena contraria a un Estado que, en palabras de los líderes indígenas presentes en este documental, ha sido pensado tradicionalmente por hombres, reproduciendo un modelo patriarcal y capitalista en contra de los ideales de equidad y justicia de género de los pueblos originarios. 


\subsection{La producción visual como apuesta ético-política por el reconocimiento}

A modo de fundamentar teóricamente la creación de un portafolio fotográfico que manifieste las condiciones actuales del Cabildo Indígena Nasa de Bogotá, Colombia y sus percepciones frente a la incidencia de los medios de comunicación en sus prácticas de reconocimiento como comunidad indígena, resulta necesario precisar algunos aspectos que refieren al carácter ético - político de la imagen no solo como registro visual de la experiencia investigativa sino en términos de posibilidad narrativa y de diálogo con diversos contextos socioculturales.

Al respecto, Sontag (2006) enuncia que: "fotografiar es apropiarse de lo fotografiado. Significa establecer con el mundo una relación determinada que parece conocimiento, y por lo tanto poder" (p. 16); de modo que, los procesos de creación de las imágenes a través del lente devienen a su vez en una práctica que permite interrogar las experiencias y capturarlas; aspecto eminentemente pensado como un instrumento de poder capaz de movilizar discursos y, por qué no, transformaciones. Por ello:

Una fotografía no es el mero resultado del encuentro entre un acontecimiento y un fotógrafo; hacer imágenes es un acontecimiento en sí mismo, y uno que se arroga derechos cada vez más perentorios para interferir, invadir o ignorar lo que esté sucediendo. (Sontag, 2006, p. 26)

De forma tal que, la producción visual se convierte en una herramienta para posicionar una enunciación respecto a un fenómeno o hecho particular que, en cierta manera, también ubica una verdad por encima de otros artefactos discursivos. Una verdad visible y, como tal, subjetiva y concebida desde unos agentes en concreto que la legitiman como tal. Esto conduce a afirmar la práctica fotográfica como instancia documental desde la cual también es posible otorgar propiedades «otras» a todo aquello que constituye nuestros marcos de comprensión de la realidad.

Esta verdad se encuentra mediada por una identificación establecida en el proceso de vínculo, recepción y comprensión de lo visible. Es aquí cuando surgen los tradicionales acontecimientos como: el espectador esperando que la imagen "hable" cuando lo que en sentido estricto acontece es la operatividad de la imagen; es decir, qué se hace con ella una vez se han capturado los instantes a través del lente.

Podría decirse entonces que dicha operatividad también constituye una labor de memoria en la cual hay una intención de generar vínculos entre quién captura y quienes intervienen en el 
contexto de la imagen donde, en lo posible, los detalles son múltiples, pero no pueden escaparse ante los propósitos del fotógrafo. Pues, como diría Cartier Bresson (2003):

La memoria es muy importante, memoria de cada fotografía que, al galope, hemos tomado al mismo ritmo que el acontecimiento; durante el trabajo tenemos que estar seguros de que no hemos dejado agujeros, de que lo hemos expresado todo, puesto que luego será demasiado tarde, no podremos recuperar el acontecimiento a contrapelo. (s.p)

$\mathrm{Y}$ es que sin lugar a dudas en el trabajo de la imagen absolutamente todo consiste en un elemento fundamental que proporciona información; considerando que "en torno de la imagen fotográfica se ha elaborado un nuevo sentido del concepto de información. La fotografía no es sólo una porción de tiempo, sino de espacio" (Sontag, 2006, p. 41). De allí, la importancia de un reconocimiento previo de los escenarios y sus actores; de lo contrario, el acto de capturar imágenes consistiría en un ejercicio técnico e instrumentalizado con fines propios y sin mayores aportes a las comunidades que lo integran.

En mayor caso, es nuestra visión aquella que otorga significación a la imagen; es decir que, la fotografía como otras tantas manifestaciones de la sensibilidad humana también posee un lenguaje propio. Para este caso particular, este lenguaje no está asumido en términos de lo incomprensible, críptico o, incluso, dispendioso, pues se reafirma que el componente visual permite una comunicación abierta donde siguiendo a Bresson (2003), prima una búsqueda del equilibrio compositivo.

En efecto, la persecución del equilibrio asume la adopción de la fotografía como una herramienta de intervención social. Al respecto, el trabajo de Sebastião Salgado es sugerente para visibilizar problemáticas de gran complejidad en ciertas comunidades principalmente victimizadas.

Las fotografías de Salgado manifiestan un impacto visual que, en gran modo, adquiere el carácter de arqueología en tanto rastrea la historicidad de actos de barbarie en poblaciones que han sido foco del recrudecimiento acaecido por asuntos como la migración forzada, la violencia armada, entre otros, donde subyace la subjetividad del autor como potencial sensible, ya que:

Toda representación de la realidad es un reflejo de la misma, no una simple captura mecánica, sea cual sea el soporte material empleado —mármol, lienzo...o película 
fotográfica - implica una manipulación por parte del artista, quien nunca es un registrador aséptico. (Pérez \& Gonzáles, 2015, p. 14)

Por ello, desligar las formas de interpretar, intervenir y encontrarse en un modo sensible con realidades diversas de la producción visual correspondería a mecanizarla como objeto material y, por consiguiente, restarle todo su equilibrio y su composición. Siguiendo a Cartier Bresson (2003):

...Pero todo esto hace sólo referencia al contenido de la imagen y, para mí, el contenido no puede separarse de la forma; por forma entiendo una organización plástica rigurosa en virtud de la cual, únicamente, nuestras concepciones y emociones devienen concretas y transmisibles. En fotografía, esta organización visual no puede ser más que el fruto de un sentimiento espontáneo de los ritmos plásticos. (s.p)

De esta manera, pensando en la fotografía como peldaño para interrogar la cultura es admisible mencionar que, aunque nos encontremos en un espacio tiempo ávido de imágenes, resultan pertinentes las propuestas fotográficas que más que construir sobre lo existente permitan alimentar nuevas discusiones sobre aquello que, aunque presente, ha sido secundarizado y, en consecuencia, representado a través de eufemismos o prácticas de menosprecio que poco o nada aluden a la realidad de los sujetos de referencia. Por tal motivo, no sobra reiterar las palabras de Cartier Bresson (2003) cuando insiste que:

"La cámara fotográfica no es un instrumento apto para responder al porqué de las cosas, sino más bien para evocarlo y, en el mejor de los casos, a su manera intuitiva, cuestiona y responde a la vez" (s.p). 


\section{METODOLOGÍA}

\subsection{Investigación cualitativa y sistematización de experiencias}

La presente investigación concibe el enfoque cualitativo atendiendo a una praxis que aborda realidades de carácter subjetivo; esto es, las experiencias en términos de reconocimiento y en vínculo con los medios de comunicación del Cabildo Nasa ubicado en la Ciudad de Bogotá, Colombia.

En este orden, este enfoque supone a diferencia de un enfoque cuantitativo caracterizado por la precisión de los datos medibles y las hipótesis a priori de la investigación, un desarrollo de problematizaciones en el curso de la misma. Según Sampieri (2014): “la acción indagatoria se mueve de manera dinámica en ambos sentidos: entre los hechos y su interpretación, y resulta un proceso más bien "circular” en el que la secuencia no siempre es la misma, pues varía con cada estudio" (p. 7).

Siguiendo al autor, el enfoque cualitativo, aunque flexible no escatima en la rigurosidad de la inmersión investigativa, pues es necesario en ocasiones retornar a los fundamentos o conocimientos previos al proceso investigativo con miras a ampliar o, incluso, ajustar los asuntos problémicos sobre los cuales se cuestiona el investigador. Este último, cabe señalar, no es una tabula rasa y menos aún un conocedor totalitario de todo lo que acontece en el contexto en mención, pues si bien el investigador posee unos conocimientos específicos, el enfoque cualitativo alimenta los propósitos de asumir una práctica dialogante con ellos y los saberes ancestrales de la comunidad para este caso en concreto.

Según Sampieri (2014):

La inmersión inicial en el campo significa sensibilizarse con el ambiente o entorno en el cual se llevará a cabo el estudio, identificar informantes que aporten datos y guíen al investigador por el lugar, adentrarse y compenetrarse con la situación de investigación, además de verificar la factibilidad del estudio. (p. 8)

De manera que, aunque exista una suerte de columna vertebral u hoja de ruta que guía al investigador, las transformaciones en el contexto sociocultural tanto como la infinidad de posibilidades que se presentan en su trabajo de campo, no son previsibles y, por ello, enriquecen 
su acción como creador y profesional capaz de sortear de manera asertiva las vicisitudes que se presenten en el desarrollo de su ejercicio.

De esta manera, la investigación cualitativa se presenta como una labor inductiva en tanto se parte de la exploración y la descripción para generar discusiones de orden epistemológico. En dicha inducción subyace la figura de la reciprocidad y, en efecto, de la triangulación como principio de análisis de las experiencias y resultados más que los datos. Esto quiere decir que:

...En un estudio cualitativo típico, el investigador entrevista a una persona, analiza lo que obtuvo y saca conclusiones; posteriormente, entrevista a otra persona, analiza esta nueva información y revisa sus resultados y conclusiones; del mismo modo, efectúa y analiza más entrevistas para comprender el fenómeno que estudia. Es decir, procede caso por caso, dato por dato, hasta llegar a una perspectiva más general. (Sampieri, 2014, p. 8)

En este análisis de resultados y experiencias de investigación, es menester mencionar que, en función de la aproximación cualitativa, el investigador asiste a un "desarrollo natural de los sucesos, es decir, no hay manipulación ni estimulación de la realidad" (Corbetta citado por Sampieri 2014, p. 8), aquello que implica que, para este caso en particular, el investigador realiza un trabajo de campo no como totalmente participante pero sí como intérprete, pues para el hecho en mención, es el lente fotográfico el que posibilita el diálogo con los agentes que precisan sus experiencias a través del componente narrativo ${ }^{7}$.

En consecuencia, considerando que la presente investigación otorga mayor primacía a la experiencia que a la práctica de recolección de datos concretos, se adoptan postulados de la sistematización de experiencias como una perspectiva interpretativa que ha sido ampliamente enriquecida en el trabajo con poblaciones en Latinoamérica. Según Carrillo (1997), uno de los propósitos de la sistematización es "la preocupación por producir saberes que amplíen los marcos de acción y comprensión de las experiencias de trabajo popular” (p. 28). De allí que, sistematizar implica una nueva producción de conocimiento desde la cual las realidades sociales no pueden someterse a la inmutabilidad de los postulados teóricos sino al dialogismo e interpretación de las mismas "para ser reconocida como una construcción colectiva de

\footnotetext{
${ }^{7}$ Con miras a profundizar la adopción del componente narrativo en la presente investigación, revisar el apartado 4.2 del presente documento.
} 
sentido, como un tejido de relaciones sociales y culturales históricamente conformado" (Carrillo, 1997, p. 30).

A razón de lo anterior, esta sistematización de la experiencia investigativa como del proceso relacional con la comunidad indígena, tiene su hecho práctico en la consolidación del portafolio fotográfico $^{8}$ no sin antes atravesar todo aquello que lo ha fundamentado; esto es, la reconstrucción de la experiencia que, en lo que refiere a esta investigación, se desarrollará de la siguiente manera:

Tabla 1. Reconstrucción de la experiencia

\begin{tabular}{l|l}
\multicolumn{1}{c|}{ Pasos metodológicos } & \multicolumn{1}{c}{ Recursos } \\
\hline $\begin{array}{l}\text { 1. Confrontación de las distintas categorías } \\
\text { de actor. }\end{array}$ & Historias de vida \\
& Diarios de campo \\
\hline $\begin{array}{l}\text { 2. Confrontación de las versiones y } \\
\text { periodización endógena. }\end{array}$ & Caracterización de la comunidad indígena. \\
\hline $\begin{array}{l}\text { 3. Estructuración y puesta a prueba de un } \\
\text { macro - relato consensual. }\end{array}$ & Portafolio fotográfico. \\
$\qquad$ \\
Fuente: Carrillo (1997). Adaptación propia.
\end{tabular}

En este orden de ideas, las categorías de actor son "construcciones que buscan establecer las relaciones y funciones de los actores en el desarrollo de la experiencia" (Carrillo, 1997, p. 47), es decir, las construcciones narrativas que sustentan el quehacer investigativo: las historias de vida de 4 integrantes del Cabildo Nasa de Bogotá, Colombia y, a su vez, los diarios de campo propios del investigador cuyo diseño es el siguiente:

\footnotetext{
${ }^{8} \mathrm{Al}$ respecto, se establecerán algunas claridades en el apartado 4.3 del presente documento.
} 
Diario de campo No.

\begin{tabular}{l|l}
\hline Fecha & \\
\hline Lugar & \\
\hline Momento & \\
\hline Descripción de la experiencia & \\
\hline Comentarios y reflexiones & \\
investigativas & \\
& Fuente: elaboración propia.
\end{tabular}

El diario de campo constituye un instrumento de registro de información significativa en el proceso de inmersión investigativa. Al ser el componente narrativo el eje transversal de la presente investigación, se adopta el diario o cuaderno de notas como una estrategia reflexiva que, haciendo uso de la escritura, permite al investigador detallar de manera precisa el encuentro y trabajo directo con la comunidad.

Estos dos recursos que integran el primer paso metodológico de la tabla 1, sustentan la consecuente confrontación de las versiones y periodización endógena ${ }^{9}$ que, siguiendo a Carrillo (1997) refiere a:

La reconstrucción de la experiencia en términos de las perspectivas de los distintos actores en ella comprometidos, para establecer, de la manera más completa posible, el vínculo entre el proyecto que supone la experiencia y las características socioculturales del grupo participante. (p. 48)

Desarrollando el momento de reconstrucción de la experiencia con la caracterización de la comunidad, se procede al tercer y último paso metodológico de estructuración y puesta a prueba de un macro - relato consensual, donde destaca la producción fotográfica como eje narrativo para visibilizar la experiencia con la comunidad indígena y, por supuesto, las reflexiones críticas emergentes del investigador en diálogo con los integrantes del cabildo.

\footnotetext{
${ }^{9}$ Este segundo paso metodológico se desarrollará con mayor énfasis en el capítulo 5 de desarrollo investigativo sistematización de la experiencia.
} 
Así las cosas, se mencionan a continuación algunos aspectos metodológicos a considerar sobre el componente narrativo en el marco de la investigación cualitativa y la sistematización de la experiencia que sustenta el proyecto en mención:

\subsection{Componente narrativo: relatos de vida y entrevistas}

Con motivo de abordar el carácter sensible del reconocimiento como instancia de construcción de identidad, se realiza énfasis en la generación de 4 relatos de vida principalmente a través de la producción oral; lo anterior teniendo en cuenta la importancia de la oralidad en las prácticas de comunicación ancestral.

Estos relatos cuya transcripción se realiza a posteriori, se caracterizan por su enunciación en primera persona, aspecto que refiere a la subjetividad del emisor y del cual se parte para realizar la interpretación de los modos de reconocimiento y menosprecio existentes en parte de la comunidad indígena. Desde allí, se parten de los fundamentos de Bertaux (2005) desde los cuales las narrativas no poseen un desarrollo lineal, pues parten de la experiencia subjetiva de los sujetos. Para el caso particular, y siguiendo a Bertaux (2005), los relatos de vida recogidos en el trabajo de campo indagan frente a tres ejes u objetos sociales:

1. Mundos sociales: constituye todos aquellos macros, meso y microcosmos en los cuales se desenvuelve la experiencia humana, aquello que, en gran medida, conduce a indagar en los contextos tanto discursivos como sociales en los cuales están inmersos los integrantes del cabildo en mención.

2. Categorías de situación: encabezadas por la primacía de las situaciones particulares o aquellos acontecimientos que distinguen un relato y experiencia de vida respecto a las demás.

3. Trayectorias sociales: o historicidad (secuencia temporal) de las experiencias humanas; esto es, todas aquellas prácticas, situaciones o discursos que hacen posible el lugar de enunciación del sujeto.

Estos tres componentes permiten concebir el relato de vida bajo una experiencia filtrada que, parafraseando a Bertaux (2005) ocurre cuando el investigador convoca a los sujetos al hacer narrativo a través de un camino trazado propio de la perspectiva etnosociológica. De manera 
que, con motivo de esclarecer los modos de reconocimiento y menosprecio asociados a los vínculos de los 4 integrantes del cabildo con los medios de comunicación, se conciben los siguientes aspectos a manera de posteriores cuestionamientos que direccionan dicha experiencia y narrativa por parte del investigador:

Figura 1. Cuestionamientos guía para la generación de relatos de vida.

Concepciones particulares respecto al ser, sentir y devenir indígena en contextos urbanos.

Afirmaciones en torno a las identidades autóctonas y el pensamiento ancestral como comunidades étnicas.

Acercamientos o acción directa con medios de comunicación tanto propios como de dominio privado.

Percepciones frente al devenir indígena presentado en medios de comunicación reconocidos como nacionales.

Posicionamientos acerca del lugar del indígena y su ancestralidad en la vida cotidiana y el relacionamiento con comunidades «otras» pertenecientes a la ciudad-país.

Reflexiones en torno a las violencias simbólicas subyacentes al devenir indígena en contextos de victimización sistemática.

Fuente: elaboración propia.

En este orden de ideas, los relatos de vida que se presentarán en páginas siguientes atienden a tres funcionalidades (Bertaux, 2005):

1. Función de exploración, como una suerte de tanteo de las situaciones narrativas donde el investigador "pone en tela de juicio las ideas preconcebidas con que llegaba" (Bertaux, 2005, p. 53) y, a su vez, aprende y desaprende de los conocimientos proporcionados por los sujetos.

2. Función analítica, en la cual el relato devela pistas diversas para comprenderlo y profundizar en él. Es en este aspecto donde la transcripción y la relectura cobran sentido. Con ello, el investigador relaciona críticamente los aspectos principales de la narrativa con miras a 
triangular la información, encontrar recurrencias, etc.; es decir, cruzar la misma con sus categorías conceptuales.

3. Función expresiva, donde destaca el carácter estético y sensible de la palabra que, para el caso en concreto, es conducida a la producción visual. Aquí el relato de vida adquiere operatividad; dicho de otra manera, se genera un tránsito del poder de la narración oral a la potencia comunicativa de la imagen.

Acto seguido, se realizan 2 entrevistas de corte semiestructural ${ }^{10}$ que anteceden a la inmersión en las experiencias subjetivas de los 4 integrantes del cabildo indígena Nasa de Bogotá. Según Sampieri (2014): “las entrevistas semiestructuradas se basan en una guía de asuntos o preguntas y el entrevistador tiene la libertad de introducir preguntas adicionales para precisar conceptos u obtener mayor información" (p. 403). De forma tal que, si bien las entrevistas están pensadas a la luz de tres componentes, por sus múltiples abordajes permiten al investigador formular interrogantes espontáneos de acuerdo con el hilo discursivo de la interlocución.

Así las cosas, se presentan los tres componentes o etapas que sustentan el desarrollo de las entrevistas a realizar:

Tabla 3. Componentes para formulación de entrevistas

\begin{tabular}{l|l} 
1. Caracterización & $\begin{array}{l}\text { Interrogantes de índole global; esto es, preguntas cuyo } \\
\text { núcleo problémico permita ahondar en las condiciones } \\
\text { macro contextuales: conformación, estructuración y } \\
\text { funcionamiento del cabildo indígena. Del mismo modo, } \\
\text { se precisan interrogantes acerca del lugar de enunciación } \\
\text { del entrevistado. }\end{array}$ \\
\hline 2. Contextualización & $\begin{array}{l}\text { Interrogantes cuyo núcleo problémico permita } \\
\text { profundizar en factores micro contextuales; es decir, } \\
\text { factores relacionados con la situación de la comunidad } \\
\text { indígena en los entornos urbanos y rurales, así como las }\end{array}$
\end{tabular}

\footnotetext{
${ }^{10} \mathrm{Al}$ respecto, detallar los anexos 1 y 2 (formatos de entrevistas semiestructuradas) que se encuentran al finalizar el presente documento.
} 


\begin{tabular}{l|l} 
& $\begin{array}{l}\text { dimensiones éticas, políticas, culturales e identitarias en } \\
\text { la legitimación del movimiento social. }\end{array}$ \\
\hline 3. Opinión & $\begin{array}{l}\text { Interrogantes relacionados con aspectos propios de la } \\
\text { subjetividad del entrevistado y trastocados por las } \\
\text { subcategorías de reconocimiento y menosprecio } \\
\text { precisadas en el marco teórico de la presente } \\
\text { investigación y de interés para el cumplimiento de sus } \\
\text { objetivos. Del mismo modo, se abordan } \\
\text { cuestionamientos afines con las percepciones sobre la } \\
\text { relación comunidadindígena-medios de comunicación a } \\
\text { partir de las experiencias del hablante. }\end{array}$ \\
Fuente: elaboración propia
\end{tabular}

Con ello, se presentan a continuación unas breves precisiones metodológicas en lo que refiere a esta tercera y última función de los relatos de vida que, para la investigación en mención, está asociada a la producción de un portafolio fotográfico cuyo propósito consiste en evidenciar las condiciones del Cabildo Indígena Nasa de Bogotá, Colombia a través de sus prácticas identitarias y percepciones frente a la incidencia de los medios de comunicación en sus modos de reconocimiento como comunidad indígena:

\subsection{Portafolio fotográfico}

Con miras a la creación de un portafolio fotográfico que manifieste a través de la imagen las condiciones del Cabildo Indígena Nasa de Bogotá - Colombia a través de sus prácticas identitarias y percepciones frente a la incidencia de los medios de comunicación en sus modos de reconocimiento como comunidad indígena, se piensa en una producción visual con aproximación curatorial; es decir, a partir de un proceso analítico y reflexivo de presentación e interpretación de las imágenes contrario a una selección de las mismas y ubicación aleatoria.

En este sentido, el portafolio está dispuesto para generar un diálogo entre la fotografía y la transcripción de los relatos de vida en mención. Diálogo dispuesto a partir de los siguientes factores de interés compositivo que, a su vez, fundamentan los apartados del portafolio: 
Figura 2. Macroestructura de portafolio fotográfico.

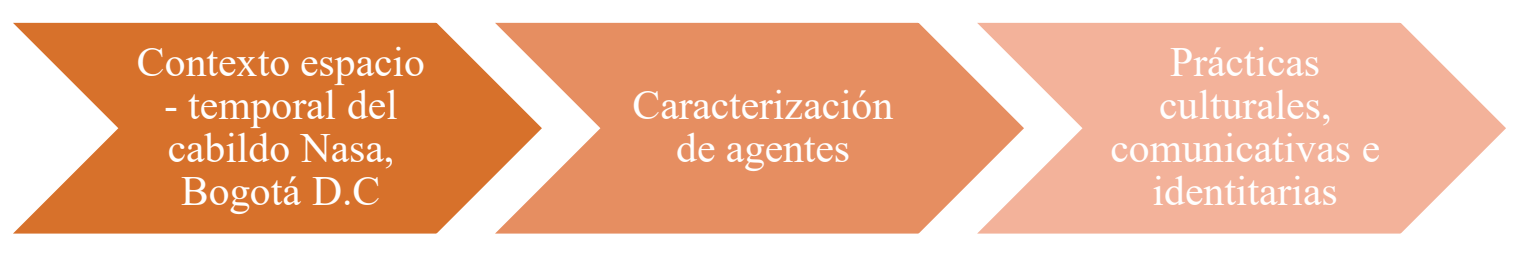

Fuente: elaboración propia.

En consecuencia, estos tres ejes están intervenidos continuamente por las narrativas pertenecientes a los relatos de vida de los cuatro integrantes del Cabildo y, seguidamente, por las interpretaciones emergentes de fragmentos de los diarios de campo que fundamentan el trabajo práctico.

Así las cosas, se presenta a continuación el desarrollo de la práctica investigativa que, fundamentada en la sistematización de experiencias, presenta de manera desglosada los hallazgos y diálogos emergentes de los dos momentos del trabajo de campo: 


\section{DESARROLLO DEL PROBLEMA}

\subsection{Acerca de la comunidad y cabildo indígena Nasa en Bogotá}

El presente apartado pretende dar cabida a la reconstrucción de la experiencia investigativa que, en términos de la sistematización de la experiencia, equivale a la confrontación de las versiones y periodización endógena a partir de una caracterización específica sobre el cabildo indígena Nasa que fue partícipe en esta investigación.

Así las cosas, es importante esclarecer que a la fecha son insuficientes los registros sobre el estado de la comunidad Nasa en la capital del país. Sin embargo, Bernal (2012), presenta algunos aspectos a considerar en lo que refiere a la resistencia cultural y la territorialidad Nasa en la ciudad.

Según la autora, la presencia del grupo indígena en Bogotá ha concluido en un posicionamiento permanente de rechazo a las formas de opresión, en tanto la ciudad implica dinámicas tanto de recepción de diversos grupos identitarios y, a su vez, micro procesos de segregación social en instancias de la vida cotidiana, tales como: el acceso laboral y la educación intercultural que aún no son un factor transversal en muchos sectores productivos y escuelas de carácter distrital y privado, etc.

Siguiendo a Bernal (2012), los Nasa han desarrollado diversas estrategias para construir territorio en Bogotá, lo cual está asociado a la generación de memoria colectiva y a las formas autónomas de gobierno donde la ciudad es percibida como:

...un lugar de intensas relaciones sociales donde se puede acceder a mejores niveles académicos y económicos; es, además, un escenario conflictivo y caótico, pues existen particulares condiciones socioeconómicas, políticas, ambientales y de heterogeneidad cultural que aceleran los procesos de aculturación. Tales condiciones marcan claramente la identidad nasa en un contexto urbano que se transforma y adquiere nuevos matices. (p. 88)

En esta idea de ciudad propia, la comunidad Nasa no solo resemantiza las prácticas de menosprecio de las cuales han sido fuertemente afectados sino genera nuevas políticas de agenciamiento cultural, esto es, instancias de reconocimiento y deliberación donde destaca la figura del cabildo como lugar para el encuentro, intercambio de experiencias y, por supuesto, 
uno de los epicentros de acción cooperativa donde se toman decisiones sobre el actuar de la comunidad en el espacio urbano con respecto a los múltiples integrantes que se encuentran en otras latitudes del país y que también son partícipes de una misma identidad. De forma tal que, en estas discusiones, "la ciudad es también vista como un escenario para obtener recursos económicos, para acceder a la educación y como un lugar político propicio para el diálogo y la concertación" (Bernal, 2012, p. 89), pues la ciudad, aunque campo en constante disputa por la territorialidad, también provee posibilidades de buen vivir en algunos casos.

A razón de lo anterior, a continuación, se presentan las consideraciones de algunos integrantes del cabildo Nasa de Bogotá quienes, en sus propias narrativas, vivifican la experiencia de reconocimiento como comunidad indígena con relación a sus prácticas propias y su relación con los discursos que circulan en los medios de comunicación nacional.

\subsection{Configuraciones de reconocimiento y menosprecio en narrativas del cabildo Nasa de Bogotá}

El momento de encuentro con la comunidad integrante del cabildo Nasa de Bogotá corresponde al paso metodológico de confrontación de las distintas categorías de actor donde a la par de las historias de vida, se desarrollan los diarios de campo emergentes de la experiencia de investigación. Este momento se sitúa en un contexto particular y determinante en el curso de la indagación: la emergencia sanitaria producto del covid-19, por lo que las intervenciones e interlocución con los sujetos en cuestión, están fundamentadas principalmente en la virtualidad como puente de comunicación.

Así las cosas, se establece un contacto con Andrés Llano, secretario del cabildo quien, a través de una entrevista realizada en el mes de diciembre de $2020^{11}$ y a sus 26 años de edad comenta que el cabildo en el cual empezó sus labores como digitador del Censo, es un espacio conformado por una estructura organizacional donde prima la asamblea representada por sus cabildantes y, a su vez, la permanencia de otras instancias como la consejería y la dirección quienes realizan un seguimiento a los procesos desarrollados en el cabildo.

\footnotetext{
${ }^{11}$ Al respecto, ver anexo 3 - entrevista a Andrés Llano.
} 
Para Andrés, los modos de tejido de vínculos de acción colaborativa entre el cabildo y el movimiento indígena Nasa que se encuentra en diversas latitudes del país, están principalmente relacionados con el diálogo constante y mancomunado desde el Consejo Regional Indígena del Cauca-CRIC- quienes gestan contactos con los distintos territorios indígenas.

Desde su percepción, la situación económica que atraviesa el devenir indígena en Bogotá parte de una carencia de seguimiento por parte de instituciones como el Ministerio del Interior quienes al no proporcionar un registro del cabildo Nasa no permiten el ingreso de recursos por parte del Estado.

Lo anterior, permite evidenciar las dificultades en términos de sostenimiento económico por las cuales atraviesan estos espacios para el fomento de las prácticas indígenas y territoriales que, al no ser contempladas dentro de la gestión pública de la ciudad, no pueden acceder a posibilidades de crecimiento y divulgación de su accionar.

En términos de los ámbitos sociales, políticos y culturales, el entrevistado manifiesta la importancia del plan de vida que traza el fortalecimiento de la identidad como pueblo y que es susceptible a su pérdida en el contexto urbano. Este último aspecto permite dilucidar que, aunque los espacios de deliberación política se mantienen, aquellas construcciones identitarias que están fundamentadas en la noción de reconocimiento como comunidad indígena, languidecen frente a las prácticas de menosprecio que, por el contrario, se mantienen.

Ante esto, el entrevistado enuncia la complejidad que se presenta en contenidos como los difundidos en medios de comunicación los cuales suelen incurrir en la legitimación de este menosprecio representado en la negación de las intenciones del actuar indígena.

Para el sujeto en mención, esto está relacionado al poder que ostentan las grandes industrias del entretenimiento y consumo en Colombia quienes se encuentran tras la propiedad de los canales televisivos, emisoras radiales, entre otros. Siguiendo al entrevistado, ello parte de una visión plenamente occidental donde factores como el capital acentúan los modos de invisibilización y desprestigio de su cosmovisión como pueblos originarios. 
Así lo plantea María Guetoto, mujer integrante del cabildo Nasa de Bogotá quien, a sus 34 años, desempeña el cargo de servicio al cliente en este espacio. ${ }^{12}$

Para María, los significados otorgados al reconocimiento y menosprecio como integrante de la comunidad Nasa, parten del acercamiento filial; es decir, sentirse partícipe de la comunidad como ser sintiente que con su labor afianza los lazos empáticos con y entre sus pares. Desde allí, María plantea que es digno de reconocimiento el amor, rescate, preservación y divulgación de su lengua materna en la medida que le permite compartir y mantener modos de unidad en contextos urbanos y hostiles como la ciudad de Bogotá.

Por ello, rescata el valor de la genealogía como salida para superar las barreras impuestas desde el menosprecio y sus manifestaciones en el espacio público; pues, siguiendo a María, es prioridad de los descendientes de la gran familia Nasa mantener y continuar el camino o legado dejado por sus hermanos mayores.

En este orden, María manifiesta que es su hijo quien constantemente relata situaciones de menosprecio y vulneración de derechos en la institución educativa a donde asiste. En este aspecto, el menosprecio adquiere el carácter de desposesión de derechos y exclusión social representado en casos cotidianos como los vividos por su hijo quien narra que es victimizado, criticado y excluido por su apellido e, incluso, por la herida colonial que aún se mantiene en la escuela.

Esta herida o deuda colonial está representada por los rezagos históricos de ostentación del poder a manos de "los blancos". Por ello, los compañeros de su hijo mencionan constantemente que existe una línea divisoria entre indígenas y "blancos" que no es posible quebrantar solamente con el hecho de compartir un mismo escenario educativo.

Situaciones como las expuestas anteriormente, develan la inmanencia del discurso de superioridad que aún, tras los inmensos esfuerzos de varias instituciones de formación educativa por generar espacios de enseñanza y aprendizaje con enfoques diferenciales, no son lo suficientes para irrumpir sobre dichas prácticas de menosprecio que continúan en vigencia.

Contrario a ello, subyacen las prácticas de reconocimiento evidenciadas en discursos de solidaridad donde el trabajo comunicativo de María adquiere gran relevancia. De acuerdo con

\footnotetext{
${ }^{12}$ Al respecto, ver anexo 4 - entrevista a María Guetoto.
} 
María, su trabajo le permite generar una sensibilización frente a otros en función de lo que se desarrolla en el cabildo.

Las experiencias de Andrés y María se relacionan con las narrativas de los 3 integrantes del cabildo indígena Nasa de Bogotá que, a través de sus relatos escriturales, manifiestan sus experiencias de reconocimiento y menosprecio ligadas tanto al lugar que adquieren los medios de comunicación nacional en sus ejercicios identitarios como a la participación dentro del cabildo:

El primer relato corresponde a Johana Tintinago quien escribe:

“...Bueno, mi vivencia o experiencia en el Cabildo es relativamente corta o nueva porque hace poco más de año y medio que vengo participando en los procesos del Cabildo. Siempre he sabido que soy indígena Nasa, pero mi familia no estaba dentro de un Cabildo, dentro de una organización.

Durante mi proceso académico universitario, yo me doy cuenta de la existencia de estos cabildos y empieza el interés por pertenecer a uno, entonces pues ya casi terminando mis estudios universitarios entré a hacer parte del Cabildo Nasa.

Al entrar y hacer parte del cabildo, ¿qué cambia en uno? La percepción de muchas cosas que cotidianamente no le daba interés como el sentido de pertenencia de Cabildo, de lo que somos, el orgullo de sentirse Nasa y la concepción de lo colectivo, porque siempre estamos pensando en una colectividad no en el bienestar individual sino lo que yo le pueda aportar a mi comunidad, incluso la forma de hablar cambia, ya no se refiere uno en términos del "yo" sino que se empieza a hablar en términos de "nosotros" y se le coge cariño al proceso, al trabajo con la comunidad y pienso que es muy importante seguir con esos trabajos que muchas veces no son lo verdaderamente valorados por la sociedad pero que tienen un papel supremamente importante que es el de salvaguardar la cultura de un pueblo ancestral que está en peligro de extinción por los diferentes conflictos que hemos vivido históricamente."

El relato de vida de Johana permite comprender que, la participación en el cabildo Nasa de Bogotá vigoriza las manifestaciones de reconocimiento como comunidad a partir de las 3 instancias: amor, derechos y solidaridad. En la perspectiva del amor se entiende un lazo de corresponsabilidad y afecto entre pares que se representa en aspectos propios de la palabra 
como la conversión de un "yo" independiente y autónomo a un "nosotros" que dentro de sí posee una carga simbólica de empatía y valoración del otro como ser humano e indígena.

El reconocerse parte del otro incide en la lucha colectiva por los derechos y, en ese orden, por la reivindicación colectiva en su devenir y sentir indígena. Tanto en el amor como en el plano de los derechos, la intersensibilidad es una constante en la medida que permite entrar en la interlocución con ese otro que no es ajeno no solo por pertenecer al mismo cabildo sino porque dentro de sí asume su pertenencia identitaria y la defensa de una cosmovisión compartida.

Finalmente, destaca la solidaridad como forma de reconocimiento donde dicha lucha colectiva tiene un mismo fin que, en palabras de Johana parte de "salvaguardar la cultura de un pueblo ancestral". En este orden de ideas, la solidaridad se reconoce más que como valor, como un compromiso, pues ser, estar, sentir y devenir indígena también parte de comprender el deber ético y político como agente de cambio y, por supuesto, de líder en la defensa y protección de prácticas ancestrales que, a fuerza de las transformaciones del contexto urbano, también están desapareciendo.

En un segundo lugar, se encuentra el relato de vida de María Guetoto quien no solo pertenece al cabildo y el movimiento indígena sino afectada por el conflicto armado interno en su territorio de nacimiento: Cauca. A través de la narración escrita, María manifiesta:

"Nací en Caldono - Cauca, estudié la primaria en la vereda Andalucía y el bachillerato lo terminé en la ciudad de Cali. Vivo en Bogotá hace 4 años y vine para la capital en busca de mejores oportunidades de trabajo y bienestar. Lo que más extraño de mi tierra es a mi familia. Me gusta la ciudad de Bogotá porque tiene trabajo y mi hijo puede recibir una mejor educación. Le inculco constantemente las tradiciones, su lengua y los valores de la comunidad.

Pienso que la política en Colombia es engañosa, prometen, pero no cumplen. Ser indígena significa orgullo, hacemos respetar nuestras creencias para que los demás tengan en cuenta que también somos seres humanos, ciudadanos, colombianos. Deseo que mi hijo estudie, que tenga lo que yo nunca tuve, deseo seguir estudiando, aprender, y ayudar a los demás, quiero estudiar algo relacionado a la salud. 
Vivo en el barrio Las Cruces en Bogotá y soy madre soltera, pienso que los medios de comunicación no dicen y no muestran la realidad de nosotros, deberían mostrar lo que vive el pueblo, los hechos de violencia, tienen que mejorar mucho. Cuando viajo al Cauca llego con miedo por todo lo que tiene que ver con la violencia que padecemos, lo mejor es hacer la paz, dialogar entre todos.

He trabajado en casas de familia como empleada doméstica, cuidando a algunos adultos mayores, pero el cabildo Nasa para mí se convirtió en mi familia acá en Bogotá. Al principio estaba muy sola, y sufrí, pero ahora, comparto y disfruto mucho con los demás."

El relato de María Guetoto enfatiza en el reconocimiento como sinónimo de orgullo. Si bien para María es plenamente importante salvaguardar el patrimonio inmaterial del pueblo indígena Nasa en Colombia, le otorga gran relevancia al reconocimiento desde la humanidad. Esto último radica en la esfera del derecho que, parte de identificar y comprender aquellas deudas históricas que la sociedad colonial ha dejado en las poblaciones víctimas de silenciamiento y anulación.

Por ello, la humanidad está relacionada con la necesidad de reconstrucción de tejidos sociales lo suficientemente consistentes como para albergar en un mismo contexto urbano tanto indígenas como demás ciudadanos independientemente de sus filiaciones políticas o culturales.

En el relato de María destaca la añoranza como síntoma de una desposesión de derechos, pues ante la imposibilidad de María por acceder a un trabajo con condiciones óptimas, sucede su migración a la capital del país. Este aspecto demarca la carencia de bienes y servicios que, en calidad de seres humanos amparados por la Constitución, deberían poseer todos los ciudadanos en las mismas condiciones.

En efecto, se hace énfasis en el componente de la equidad como entrada al reconocimiento. Interpretando el relato de María, no basta con la apertura gradual de espacios para la inclusión y atención a poblaciones diversas si continúan parciales o inexistentes las posibilidades de acceder a una vida digna.

Finalmente, se presenta el lugar de los medios de comunicación nacional como un mecanismo de indignidad, injuria y deshonra. María manifiesta que a través de los canales informativos es 
muy frecuente la tergiversación de la información y, por lo anterior, el ocultamiento de situaciones verídicas y en tiempo presente que acontecen en cada uno de los territorios, sobre todo, en aquellos que son afectados por el conflicto armado interno colombiano.

Ante este panorama, acontece y persiste el miedo como una emoción desencadenante de momentos de sufrimiento, dolor y barbarie provocados en el marco de los actos bélicos. Esto es determinante ya que son las manifestaciones del menosprecio las que derivan en la instauración de determinadas emociones en los sujetos, pues el menosprecio no se presenta de manera eventual, sino que, por el contrario, devela huellas en las corporalidades y las experiencias sintientes de toda una población.

Seguido a la narrativa de María Guetoto, se encuentra el relato de vida de María Edilma Pascué. María Edilma narra no solo parte de su genealogía familiar, factor determinante para reconocer su devenir indígena y su incidencia en el reconocimiento, sino el lugar que adquieren las dinámicas propias del conflicto armado interno en la aniquilación de las prácticas identitarias como comunidad ancestral y, por supuesto, el deterioro de la idea de territorialidad que ha desarrollado en función de su lugar de habitabilidad durante gran parte de su vida. De acuerdo con lo anterior, la narrativa de María Edilma enuncia lo siguiente:

"Nací en corinto (Cauca) hace 60 años en un núcleo familiar compuesto por 4 hermanos, los cuales, ante la pronta partida tanto de mi madre como de mi padre, asumieron diferentes roles. En este caso, mi hermana mayor asumió la responsabilidad de los hermanos menores. Solo tenía 3 años cuando mis padres murieron y recibi el apoyo de mi hermana mayor quien asumió el reto la crianza.

Los días en este territorio del cual tenemos la referencia de ser una zona de un álgido conflicto debido a la presencia de grupos al margen de la ley aunado a los conflictos familiares por la tenencia de la tierra, repercutieron en nuestra partida y el desplazamiento hacia otra región. En este caso, es el Valle del Cauca el lugar que recibe en su mayoría a las personas que huyen del conflicto armado o de la pobreza. Esta situación determinó en gran parte la forma cómo los habitantes de estas zonas asumimos nuestra realidad.

El municipio receptor fue Dagua, específicamente, el corregimiento del Queremal en donde en una pequeña parcela heredada de mis padres, encontramos una oportunidad de crecer alejados de la violencia y la pobreza. 
Pasé toda la niñez y una parte de mi juventud en esta región recibiendo educación básica primaria y parte de la cultura en tareas referidas al campo el cual se encuentra sumido en el total abandono por parte del estado.

Los bajos precios, y los bajos salarios presionaron la búsqueda de alternativas de subsistencia. En este caso, las grandes ciudades son receptoras de gran parte de las personas del campo. No fui la excepción y, por ello, decidí trasladarme a la capital del departamento del Valle del Cauca.

Cali fue el sitio en donde ante la baja escolaridad comencé mi vida laboral bajo la informalidad en tareas referentes al cuidado de niños, cocina y aseo. La discriminación por mi condición de indígena es una constante en una sociedad que asume dentro de sus imaginarios una mayor valía de aquellos que por su conocimiento y status social deben ser los destinados a recibir un mayor respeto.

En cuanto a la mirada que tengo acerca de cómo los medios presentan la información de mi comunidad, está claro que se presenta solo las imágenes de lo que hacen los indígenas cuando se defienden de la agresión de los militares, pero nunca muestran cómo la fuerza pública entra a los territorios para agredirnos sin el consentimiento de la comunidad.

Entiendo que es un reclamo justo de restitución de derechos y siento miedo por la forma en la que el estado actúa ante quienes denunciamos los abusos del gobierno."

El relato de vida de María Edilma conecta con la idea propuesta por Bertaux (2005) acerca de los mundos sociales. En esta narrativa, los mundos sociales que develan la experiencia humana conducen a reforzar la existencia de contextos de hostilidad y desolación que toman parte en el conflicto armado y el desplazamiento forzado. Por ello, este relato constantemente acude a la rememoración de los espacios habitados, territorios receptores de un nuevo proyecto de vida $\mathrm{y}$, en otros casos de su historia, de memorias compartidas entre habitantes que han forjado toda una vida en el campo, pero que, por asuntos principalmente violentos, se encuentran obligados a migrar a la ciudad.

Los mundos sociales son fundamentales para leer a María Edilma en clave de reconocimiento, por lo que permiten interpretar que el reconocimiento está asumido en clave de derechos. La restitución y la desposesión de estos afecta el curso de su devenir indígena por lo que da valor a la resistencia como punto de escape ante las consecuencias que genera el menosprecio en su construcción individual. 
Del mismo modo, se presentan las trayectorias sociales que también están imbricadas en las categorías de situación planteadas por Bertaux (2005). En este caso particular, María Edilma acude a la reconstrucción autobiográfica para precisar una secuencia de hechos en un marco temporal. Estos hechos permiten establecer una nueva clave de menosprecio: la asociación indígena-deshonra. Frecuentemente se enuncia que su labor de supervivencia en la ciudad ha estado marcada por las jornadas laborales como trabajadora informal, ama de casa al servicio de otras familias, etc.

Estas situaciones no son ajenas a su devenir indígena Nasa, pues en contextos de status de poder se suele legitimar este tipo de prácticas de adoctrinamiento donde resurge la imagen colonial de la superioridad. En otras palabras, el indígena se encuentra ante el juego absurdo del servicio a aquellos que ostentan la riqueza material y que poseen bienes adquisitivos superiores.

Los tres relatos de los partícipes del cabildo indígena Nasa de Bogotá manifiestan las afirmaciones en torno a las identidades autóctonas y de pensamiento ancestral como integrantes de una comunidad étnica acudiendo a acontecimientos que han impactado en sus historias de vida.

Por lo anterior, se reconoce que las consideraciones sobre su lugar de enunciación como indígenas no son en nada disímiles con las microhistorias que también acontecen en la ciudad y que pertenecen a ciudadanos que no son indígenas. Ello manifiesta un diálogo intercultural de gran relevancia que demanda fortalecerse no solo con miras de afianzar las prácticas del buen vivir con enfoque diferencial sino para reconocerse en su mismidad ante un ejercicio empático en comunidad.

Acto seguido, se hacen latentes las violencias simbólicas que están asociadas al mal-decir, a la agresión, victimización y exclusión social a las cuales son sometidos los grupos indígenas, En los casos particulares, estas violencias varían conforme a los contextos situacionales; dicho de otra manera, las manifestaciones de menosprecio son diferenciales en el campo con respecto a la ciudad. En la mayoría de las narrativas, impera la violación a la integridad, el maltrato simbólico y la desposesión de derechos en contextos urbanos y una agudización de todos los anteriores en la ruralidad con ocasión del conflicto armado interno.

Tras la función exploratoria propuesta por Bertaux (2005) en la cual se realiza un diagnóstico de las situaciones narrativas indagando en los conocimientos de los sujetos a partir de sus 
experiencias como indígenas, acontece la función analítica que permite exteriorizar las anteriores interpretaciones sobre las narrativas mencionadas que adquieren sentido con esta lectura entre líneas.

Finalmente, se atiende a la función expresiva que, siendo transversal al portafolio fotográfico anexo al documento en mención, admite un destacamiento del sentir y pensar de los actores donde es el relato oral y escrito el que da lugar a la producción de la imagen.

Por lo anterior, a continuación, se desarrolla un apartado de diálogo entre esta función expresiva y el lugar que uno de los partícipes de esta investigación otorga a los medios de comunicación en su posicionamiento como indígena Nasa.

\subsection{Percepciones sobre discursos en medios de comunicación nacional}

El segundo momento de la experiencia investigativa en mención partió de la identificación del lugar de los medios de comunicación en la configuración de prácticas de reconocimiento en la comunidad indígena Nasa para la caracterización de sus experiencias de interacción mediática. Para ello, se realizó una sesión de trabajo colaborativo segmentada en dos partes:

Una primera etapa relacionada con el plano de la contextualización donde previamente se desarrolló un material audiovisual que consta de un clip audiovisual que recopila 12 fragmentos informativos procedentes de emisiones televisivas y difundidas a nivel nacional donde se narran hechos noticiosos relacionados con la relación Estado-indígenas-fuerza armada. ${ }^{13}$

El clip cuya duración es de siete minutos consta de cápsulas informativas emitidas en medios de comunicación nacional y ampliamente difundidos en Colombia. Se desarrollan situaciones relacionadas con las protestas indígenas, el movimiento social y la exigencia de reivindicaciones ante la autoridad nacional. Posterior a la proyección del video, los partícipes de la investigación manifestaron que a pesar de tener claro que se padece una estigmatización por parte de algunos medios de comunicación, aun les causa asombro el ver como son señalados, y todos sus actos son sacados fuera de contexto, con el único fin de que la opinión pública se forme unas ideas negativas sobre el indígena colombiano, ese es el verdadero problema, dice uno de los líderes del cabildo, mientras hace una pausa, y menciona que al ver todas las mentiras que se dicen de ellos, siente rabia, casi todos los días salen noticias de este

13 https://www.youtube.com/watch?v=tbhJ8VbB4bM 
tipo en todo el país, el pueblo colombiano ya tiene mentalizado que no solo el pueblo nasa hace parte de grupos armados al margen de la ley, comenta la señora Carmen, quien se encarga de la organización, logística de todos los eventos culturales que realiza la comunidad en la ciudad, no solo nosotros somos perseguidos, son todos los pueblos indígenas de Colombia, a los que le apuntan, porque en ultimas, todos somos uno solo, somos un solo pueblo originario colombiano, y la gente ya cree que nosotros queremos todo regalado, que somos delincuentes, que somos narcotraficantes, que somos violentos, todo eso es culpa de los periódicos, y de los noticieros, que por muchos años se han encargado de desprestigiar a la población indígena, nunca hacen una investigación periodística a profundidad, como se debe, le muestran a la ciudadanía lo que les conviene, y lo que le conviene al estado corrupto, porque la verdad es esa, son aliados, el gobierno necesita de los medios de comunicación para hacer lavados de cerebros, y para perseguir a todo aquel que luche por los derechos humanos.

Los integrantes de la comunidad que observaron el video coinciden en manifestar la fuerte impotencia que despierta en cada uno de ellos, porque lo que más desean es que los demás compatriotas los apoyen en sus luchas, que se solidaricen con los indígenas, que se sientan orgullosos de sus labores, que entiendan que el indígena colombiano quiere vivir en paz en sus territorios, trabajar la tierra, conservar sus tradiciones, educar a sus hijos, que desean un país pacifico, un país equitativo, e igualitario. El cabildo Nasa Bogotá sabe que el camino es bastante largo, que no están dispuesto a permitir intimidaciones, ni rechazos, que, a pesar de las dificultades, y de esos enemigos tan poderosos, la comunidad permanece unida, día a día dan a conocer sus ideales, sus prácticas identitarias al hermano menor, como llaman los indígenas a todos los que no pertenecen a un grupo étnico, con el fin de obtener su apoyo, y entre todos, construir una nueva sociedad donde prevalezca la libertad y el respeto.

A razón de lo anterior, se dio lugar a una segunda etapa donde se recurrió a la herramienta corpográfica para develar las percepciones sobre medios de comunicación en función de las construcciones identitarias propias del devenir indígena. Para ello, se desarrolló un material alusivo a los diálogos corpográficos a partir del recurso audiovisual. A continuación, se presenta el desarrollo de una de las participantes María Edilma Pascué: 


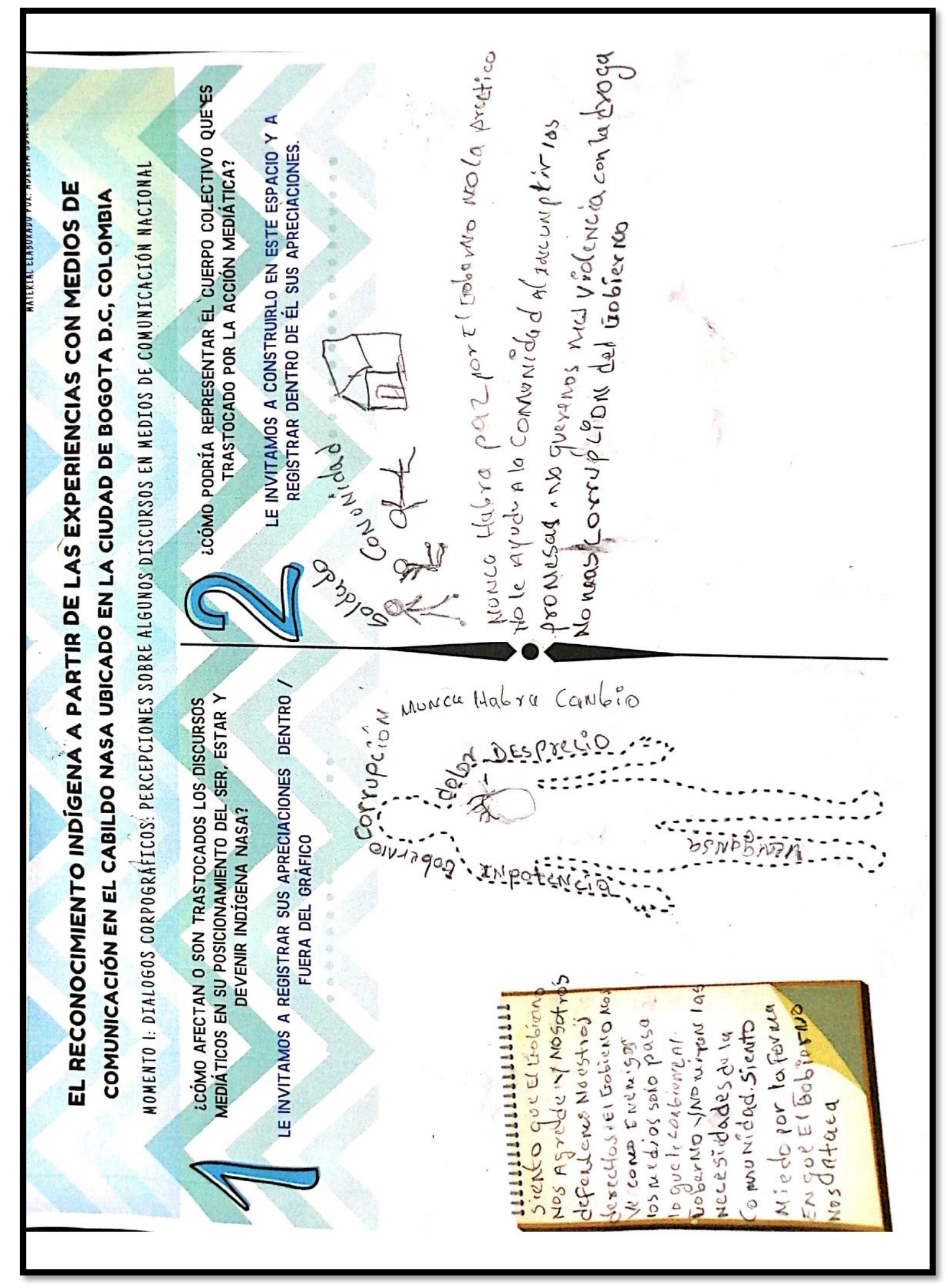

Imagen 1. Evidencia de ejercicio corpográfico posterior a la discusión sobre el clip audiovisual. Captura propia. 
En su corpografía, María Edilma manifiesta emociones de indignación y miedo relacionadas con las prácticas de menosprecio que se ejercen desde el Estado en distintos territorios indígenas, principalmente en los que refieren a la ruralidad. Por ello, se denota una frontera entre el ámbito gubernamental y las exigencias políticas del movimiento indígena que, a la luz de la reiterada desposesión de sus derechos, demanda acciones inmediatas para su restitución.

Son de gran relevancia las emociones asociadas con las formas de menosprecio respecto a los contenidos informativos en medios de difusión nacional que están relacionadas con la corporalidad de María Edilma. Destacan el dolor y el desprecio como emociones que impactan el sentir y que son resultado de las constantes contradicciones y manipulaciones mediáticas que tienen lugar en los discursos hegemónicos que circulan principalmente en la televisión.

Por otro lado, se hace evidente una total inconformidad frente a las dinámicas armadas que han ocasionado asuntos como el desplazamiento forzado, por lo que emociones como la venganza se relacionan en las extremidades inferiores, los mismos pies que caminan decenas de kilómetros lejos de su lugar de origen en busca de oportunidades más favorables el alcance de un buen vivir.

Finalmente, se estiman las proyecciones o las percepciones sobre cuerpos colectivos, entendiendo que, como grupo étnico y pluricultural, los indígenas Nasa asumen desde su cosmovisión la idea de comunidad. En estas consideraciones, María Edilma devela nuevamente la desconfianza emergente de la carga simbólica y corporal ocasionada por el menosprecio en su experiencia como mujer indígena.

Tras la firma del acuerdo para la terminación del conflicto entre el gobierno colombiano y la guerrilla de las FARC-EP, estas exigencias de paz, culminación de la violencia y erradicación de los cultivos ilícitos, entre otros, son constantes en las narrativas de las víctimas a quienes, entre otras cosas, también se les ha señalado por motivos de criminalización de las protestas sociales que, como derecho constitucional, representan la voz y necesidad de reivindicación.

En consecuencia, la práctica fotográfica que se detalla a continuación hace énfasis en los modos de reconocimiento evidenciados en el cabildo indígena Nasa de Bogotá. 


\subsection{Desarrollo de portafolio fotográfico}

Según Briot (2004), la palabra portafolio viene del francés porte folio; folio se relaciona a una página de un periódico y porte significa llevar. Un portafolio es una serie de fotografías minuciosamente seleccionadas, con diferentes intenciones, ya sea de ilustrar el estilo y calidad del trabajo del fotógrafo, o evidenciar, mostrar una historia, un hecho o una realidad. Las fotografías elegidas deben tener una razón, concordancia, lógica y un diálogo entre sí para contar una historia. Se debe fotografiar con un propósito y un fin en mente para que cada portafolio fotográfico tenga un objetivo o tema específico y poder clasificar su trabajo en diferentes categorías como paisajes, productos, retratos o eventos.

Entre los diferentes tipos de portafolios fotográficos encontramos:

- Por color: portafolio que incluya solamente fotografías en blanco y negro, en sepia o a color.

- Área geográfica: imágenes tomadas en determinado lugar

- Por formato: imágenes que sean tomadas en un formato específico, como $35 \mathrm{~mm}$, medio o grande.

- Período específico de tiempo: un viaje, año específico u otro marco de tiempo

- Por tema: imágenes que representan una idea o concepto previamente definido. Del tema establecido se derivan las fotografías.

- Diferencia radical: imágenes que son diferentes al trabajo que comúnmente el artista realiza.

En este caso, se estableció un trabajo en conjunto, unir el portafolio geográfico y el portafolio por tema, teniendo en cuenta que se trata de un pueblo originario, interactuando en su diario vivir con una ciudad cosmopolita, como la capital colombiana. A su vez se hace énfasis en la fotografía documental, entendiéndose esta herramienta como una huella, que hace memoria colectiva e histórica, desde la comunicación cotidiana, especificando solamente el momento en que ésta se genera, pero aclarando que antes y después de ese momento existen gestos culturales codificados que dependen de decisiones humanas.

Resaltando también el rol del investigador - fotógrafo que posee unas características bien claras en la comprensión del otro como lo fundamental de la realidad que puede plasmar en una fotografía o una serie de fotografías centradas en el referente, y no en el fotógrafo, es decir que produzca fotografías más reflexivas, más vivenciales, más cercanas, o un tanto más verosímil. 
El oficio inicia mirando al otro, dejando que la percepción haga su trabajo, que a través de la observación flotante, desde los sentidos, empiece a tomar forma hasta volverse un documento fotográfico que se puede descifrar, el investigador-fotográfico debe hacer un viaje al mundo del otro hasta que se da ese momento espontáneo y natural en que el mundo del otro es comprendido hasta lograr hacer un viaje al interior del que es observado y ese "mundo nuevo" aparece en imágenes lo más fiel posible a la realidad que se desea comprender y comunicar en determinadas investigaciones sociales.

El primer paso para la elaboración del portafolio fotográfico, una vez fueron establecidos los acuerdos con la comunidad, donde se resaltaba el acompañamiento que se haría, la labor que se llevaría a cabo, tanto investigativa, como fotoperiodística en algunos casos, y obtener el permiso por las autoridades máximas del cabildo, se elabora un breve cronograma de trabajo, con el fin de tener una mejor organización, planificar, y visualizar los procesos de ejecución que requiere la creación de un portafolio, que a su vez, estaba sincronizado con los distintos encuentros que tuvo la comunidad indígena: eventos culturales, reuniones, marchas pacíficas en las calles, celebraciones relacionadas a su cosmovisión, de igual manera, las visitas a algunos hogares de los integrantes del cabildo, con el fin de establecer encuentros más íntimos, que se reflejarían a partir de la imagen.

\section{Cronograma de trabajo}

\begin{tabular}{|l|l|}
\hline Búsqueda, Información y Referencias & Del 19 mayo al 20 de julio 2019 \\
\hline Pre-Fotografías & $\begin{array}{l}05 \text { de agosto } 2019 \text { (casa de pensamiento } \\
\text { indígena - Bogotá D.C. Barrio la candelaria) }\end{array}$ \\
\hline Segunda Sesión Fotográfica & $\begin{array}{l}25 \text { de noviembre 2019 (hogares de } \\
\text { integrantes del cabildo Nasa Bogotá.) }\end{array}$ \\
\hline Tercera Sesión Fotográfica & $\begin{array}{l}18 \text { de febrero 2020 (evento cultural en el } \\
\text { barrio Tintalito, Bogotá) }\end{array}$ \\
\hline Revisión Fotos + Pruebas, Retoques & Del 30 de marzo al 10 de abril 2020 \\
\hline
\end{tabular}




\begin{tabular}{|l|l|}
\hline Cuarta Sesión Fotográfica & $\begin{array}{l}20 \text { de octubre } 2020 \text { (marchas por las calles } \\
\text { de Bogotá) }\end{array}$ \\
\hline Quinta Sesión Fotográfica & $\begin{array}{l}24 \text { de febrero } 2021 \text { (reunión planetaria de la } \\
\text { ciudad de Bogotá - celebración } 50 \text { años del } \\
\text { CRIC: Concejo regional indígena del cauca) }\end{array}$ \\
\hline Elección Previa de Fotos & Del 28 de febrero al 03 de marzo 2021 \\
\hline Edición de fotografías seleccionadas & Del 05 de marzo al 07 de marzo 2021 \\
\hline $\begin{array}{l}\text { Escritura de introducción, y textos que } \\
\text { acompañan las fotografías. }\end{array}$ & Del 09 de marzo al 11 de marzo 2021 \\
\hline $\begin{array}{l}\text { Elaboración, Diagramación, y finalización } \\
\text { del portafolio fotográfico. }\end{array}$ & Del 20 de marzo al 23 de marzo 2021 \\
\hline
\end{tabular}

En lo que corresponde a la técnica, se utilizó una cámara Nikon D5600, con un lente 18-55 mm y un teleobjetivo de 70-200 mm, para hacer panorámicas más amplias; la cámara siempre en manual, manejando diferentes planos, diafragmas amplios, y velocidades altas y en ráfaga, buscando las mejores alternativas para establecer una excelente composición; iso alto de 3200; en la mayoría de las fotografías se utilizó luz natural, y en los lugares cerrados, o para hacer retratos, se necesitó luces led neewer, y un reflector Flex.

Para la edición de cada una de las fotografías se empleó el editor Adobe Photoshop, añadiendo herramientas básicas como recorte, brillo, intensidad, saturación, retoques sutiles que conservarían la esencia de cada foto; cada fotografía está a todo color, para generar un mayor impacto en el espectador, sobresalgan los detalles, las miradas, los rostros de los protagonistas, y transmitir una mayor realidad. Para la elaboración del portafolio como tal, se elige a Issuu, un servicio en línea que permite representar material digitalizado en formato libro, revista, periódico, en este caso, se decide por el formato de revista flash de mayor calidad, con la utilización de plantillas auxiliares, para una mejor maquetación y diagramación.

En el contenido del portafolio se destaca la portada, con la foto más significativa e impactante que retoma el mensaje principal a destacar, toda una colectividad en su máximo potencial de resistencia, fraternidad, y de tradición. 
Una introducción en prosa literaria, que nos acerca a la intimidad del pueblo Nasa, luego el portafolio se divide en sesiones, que a partir de las fotografías y de textos cortos que complementan la narrativa visual, destacan la labor de lo femenino en el cabildo indígena, el rol de los ancianos, sus costumbres, destacan también la simbología representada en sus bastones de mando, sus mochilas, sus ruanas, los colores, sus luchas pacificas en cada una de las calles de la ciudad que los alberga.

Desde esta producción de libro - documental fotográfico testimonial, cada una de las instantáneas, busca dar a conocer las múltiples historias del cabildo, teniendo en cuenta a la fotografía, como una de las formas de comunicación que más se extiende en todo el mundo en la actualidad, aparece para establecer desde el mismo silencio, bajo la óptica, la luz, y el sorprenderse siempre, toda la globalización existente entre el arte, y los ya congestionados fenómenos sociales, aparecen los personajes, narradores por medio de una imagen inmediata, que nos enseñan hábitos, entornos culturales, en resumen, una herramienta visual etnográfica que magnifica las costumbres, la memoria histórica, potencia los mensajes milenarios que nos ofrece una etnia que extraña su verdadero territorio.

Dichas historias hacen énfasis al reconocimiento social a partir de un colectivo ancestral que se apropia de las calles, del espacio público y privado, empuñando con orgullo sus banderas, ondeando con fuerza esos colores verdes y rojos, entrelazados con la wipala, que simbolizan la madre tierra, el verde de la naturaleza, el rojo por la sangre derramada de los indígenas que dieron la batalla a gobiernos déspotas.

Historias de identidad racial en medio de la urbe, identidades individuales, que, desde las experiencias vivenciales, sobresalen sin perder el carácter que exalta la identidad colectiva, y se ven reflejadas en sus empleos, estableciendo relaciones sociales con el otro a partir de la venta de productos autóctonos de la comunidad, de sus reuniones a puertas abiertas para hacer pedagogía con la ciudadanía, darse a conocer como cabildo indígena, elaborar proyectos empresariales, educativos, de competencias ciudadanas, entre todos, con un objetivo en común, construir una sociedad más igualitaria. Crónicas visuales donde se destacan sus rituales, sus altares, las ofrendas, manteniendo la fuerte conexión con la pacha mama.

Narrativas que enseñan el uso de medios de comunicación como las radios comunitarias para continuar trasmitiendo sus legados, ejerciendo la comunicación social en beneficio de defender y proteger a un pueblo infravalorado. Fotografías representativas de la infancia y del saber 
artístico, niños, niñas, adultos, llevando sus trajes tradicionales con orgullo, mientras danzan, o interpretan instrumentos musicales originarios de los andes.

Instantáneas en el trajinar que conlleva cada día, en cada uno de sus hogares, de sus reuniones familiares, de las ollas comunitarias que invitan a acciones reparadoras y sanadoras, compartiendo con otras comunidades indígenas, colocando en práctica la tradición oral, y el amor que se profesan entre todos, viéndose reflejado en el intercambio constante de alegrías.

Entonces encontramos en la fotografía un valor social, un valor democrático, es un medio expresivo que reproduce la existencia, constituyendo una fuente de información, que está compuesta por soportes técnicos y artísticos, que aspira a aproximarse a la interpretación verídica de los sucesos, de los hechos que en ocasiones ocurren en el entorno de aquellos que más importancia tienen dentro de una nación, producto de su sabiduría, y de las enseñanzas que pueden ofrecer.

A modo de cierre del trabajo foto-documental, se acordó con la comunidad indígena Nasa, que recibirían un total de 20 fotografías con medidas de $20 \mathrm{~cm}$ x $30 \mathrm{~cm}$ en impresión mate, asociadas al trabajo investigativo realizado, es así como se estableció una exposición fotográfica permanente en la casa de pensamiento indígena ubicada en la calle 9 No 9-60, barrio la candelaria, en la ciudad de Bogotá, Colombia, este espacio fue gracias a la gestión de la administración estatal del periodo 2012 al 2016, con el fin de agrupar a la gran mayoría de los grupos étnicos indígenas que habitan en la capital colombiana, estableciendo sus oficinas, para ejercer las labores administrativas, y organizativas, y a su vez, tener un lugar de encuentro para distintas actividades donde se manifiestan las cosmovisiones y demás tradiciones culturales ancestrales.

La exposición permanente es una forma sencilla, pero de mucho significado, de agradecer a las personas que integran el pueblo Nasa, que busca, a partir del arte, dar muestra de la fuerza, la resistencia, la empatía con el otro, de la lucha constante que mantienen a partir de sus ejercicios diarios, tejiendo hilos de unión, de tradición, inculcando en los más jóvenes, el valor de sus conocimientos, para que nunca se pierdan, y que a pesar de estar viviendo en una metrópolis, uno de sus fines, es conservar la esencia indígena, además, otro fin de la exposición permanente, es darle un aire de museo a la casa de pensamiento, aprovechando su arquitectura republicana, y que cada visitante interactúe con las fotos, y conozcan un poco más de este grupo étnico, que se enriquezcan, que despierten sentimientos, y reflexionen sobre la importancia, y el valor que deben tener nuestros ancestros en nuestra sociedad tan compleja. 


\section{CONCLUSIONES}

La investigación anterior permitió develar las manifestaciones identitarias relacionadas con los modos de reconocimiento que un grupo de integrantes del cabildo indígena Nasa de Bogotá posee a partir de su relación con el discurso de los medios de comunicación tradicionales y masivos en Colombia. Lo anterior, sobre sus narrativas de vida que develan la experiencia humana particular en el contexto urbano.

En función de lo anterior, se encontró que las exigencias en el plano del derecho como modo de reconocimiento principal detectado, manifiestan las heridas abiertas que, como sociedad, continúan sin cerrarse por motivos de la legitimación de una serie de victimizaciones que obligan a las poblaciones indígenas a generar sus propios espacios de resistencia y acción política ciertamente distantes de los discursos hegemónicos e impositivos en el plano del ejercicio de la ciudadanía.

Desde allí, el derecho también se concibe como acto de deliberación, pues de acuerdo con los relatos abordados, sentirse partícipe y cobijado por unas mismas garantías provee de suficiencias no solo económicas sino también políticas a la comunidad como unidad. En ese orden, participar en espacios democráticos al igual que identificarse como agente social en contextos de discusión donde no solo se comparten las experiencias propias del devenir indígena sino se trastocan las identidades plurales en la ciudad, permite intervenir en la construcción de ciudades más equitativas e irrumpir con las dinámicas del poder que entorpecen encuentros solidarios y en igualdad de condiciones.

Del mismo modo, se encontró que el menosprecio en tanto instancia de anulación del sentir y pensar del otro, compromete tanto la construcción de subjetividades como la continuidad y permanencia de saberes ancestrales a través de las generaciones, pues al instaurarse los modos de menosprecio como constante en las experiencias de vida, se acude a la negación de la identidad con motivo de otorgar a los descendientes condiciones de vida dignas donde no haya lugar a la victimización por su condición étnica.

A razón de lo anterior, se encontró que los modos de menosprecio no es posible categorizarlos como determinantes y secundarios en el caso particular en la medida que todos se encuentran imbricados en las experiencias de afectación de los integrantes del cabildo Nasa de Bogotá que fueron partícipes en esta investigación. 
Se halló que el conjunto que integra el maltrato y la violación a la integridad física constituyen hecho, aunque narrados de manera implícita, vivencias de difícil nombramiento que, trastocan la experiencia humana de los integrantes del cabildo y que constituyen elementos de fortalecimiento del discurso y la acción colectiva. En este ámbito, sobresale la exclusión social y la desposesión de derechos como dos prácticas de menosprecio subyacentes las cuales determinan el curso de la vida familiar y el desarrollo personal. Se presenta la adopción de un rol protagónico en la experiencia vital; sin embargo, esto trae consigo las deudas históricas y simbólicas que tras años de conflicto armado interno y rechazo en manos de gran parte de la sociedad continúan vigentes.

Finalmente, y en lo que refiere a la producción y puesta en marcha del portafolio fotográfico, cabe mencionar que, , para elaborar el portafolio fotográfico, se acordó con la comunidad indígena Nasa, que recibirían un total de veinte fotografías con medidas de $20 \mathrm{~cm}$ x $30 \mathrm{~cm}$ en impresión mate, asociadas al trabajo investigativo realizado, es así como se estableció una exposición fotográfica permanente en la casa de pensamiento indígena ubicada en la calle 9 No 9-60, barrio la candelaria, en la ciudad de Bogotá, Colombia.

Este espacio se desarrolló gracias a la gestión de la administración estatal del periodo 2012 al 2016 con el fin de agrupar a la gran mayoría de los grupos étnicos indígenas que habitan en la capital colombiana estableciendo sus oficinas para ejercer las labores administrativas, y organizativas y, a su vez, tener un lugar de encuentro para distintas actividades donde se manifiestan las cosmovisiones y demás tradiciones culturales ancestrales.

Luego entonces la exposición permanente constituyó un mecanismo de retorno; en otras palabras, de agradecimiento a las personas que integran el pueblo Nasa que busca a partir del arte dar muestra de la fuerza, la resistencia, la empatía con el otro, de la lucha constante que mantienen a partir de su cotidianidad, tejiendo hilos de unión y tradición, inculcando en los más jóvenes el valor de sus conocimientos.

Por ello, a pesar de convivir en contextos urbanos, uno de sus fines es conservar la esencia indígena aunado a la reflexión crítica sobre la importancia y el valor que deben tener nuestros ancestros en esta sociedad tan compleja. 


\section{ANEXOS}

\subsection{Formato de entrevista semiestructurada 1}

\begin{tabular}{l|l} 
Fecha: & \\
\hline Hora - lugar: & \\
\hline Tiempo de entrevista: &
\end{tabular}

Generalidades del entrevistado

\begin{tabular}{l|l}
\hline Nombres y apellidos: & \\
\hline Edad: & \\
\hline Género: & \\
\hline Ocupación: &
\end{tabular}

\section{Componente de caracterización}

1. ¿Cuál es su rol en el funcionamiento de este espacio cultural? ¿Cómo ingresa a hacer parte de él?

2. ¿De qué manera se conforma el Cabildo Nasa en la ciudad de Bogotá y cuál es su propósito?

\section{Componente de contextualización}

3. ¿Cómo se tejen vínculos de acción colaborativa entre este cabildo y el movimiento indígena Nasa que se encuentra en diversas latitudes del país?

4. Desde su posicionamiento particular, ¿cómo comprende la situación social, económica, política y cultural actual de la comunidad indígena Nasa en el país con énfasis en Bogotá?

\section{Componente de opinión}

5. En sus palabras y asociando aquello que comentaba anteriormente respecto a la situación actual del pueblo Nasa, ¿cómo concibe los vínculos e, incluso, distanciamientos entre la labor informativa propia de los medios de comunicación nacional y las luchas y resistencias del movimiento indígena en los últimos años? 


\subsection{Formato de entrevista semiestructurada 2}

\begin{tabular}{l|l} 
Fecha: & \\
\hline Hora - lugar: & \\
\hline Tiempo de entrevista: &
\end{tabular}

\section{Generalidades del entrevistado}

\begin{tabular}{l|l}
\hline Nombres y apellidos: & \\
\hline Edad: & \\
\hline Género: & \\
\hline Ocupación: &
\end{tabular}

\section{Componente de caracterización}

1. ¿Cuál es su rol en el funcionamiento de este espacio cultural? ¿Cómo ingresa a hacer parte de él?

2. Desde su experiencia particular, ¿qué implica para usted pertenecer a esta comunidad indígena?

\section{Componente de contextualización}

3. Desde la conformación del Cabildo y su participación en él, ¿qué prácticas comunicativas ejercen para preservar su pensamiento como comunidad ancestral y dialogar con diversos actores sociales que integran o no el movimiento indígena?

\section{Componente de opinión}

4. Como integrante de la comunidad indígena, ¿ha experimentado situaciones de violencia, menosprecio y desposesión de derechos por parte de otros actores del contexto urbano y rural? De ser afirmativo, ¿cuáles?

5. Respecto a lo anterior, ¿ha sido partícipe de situaciones de reconocimiento y valoración de su identidad ancestral y cultural? De ser afirmativo, ¿cuáles? 


\subsection{Entrevista a Andrés Llano}

\begin{tabular}{l|l} 
Fecha: & $15 / 12 / 2020$ \\
\hline Hora - lugar: & Cali \\
\hline Tiempo de entrevista: & presencial
\end{tabular}

\section{Generalidades del entrevistado}

\begin{tabular}{l|l}
\hline Nombres y apellidos: & Andrés Llano \\
\hline Edad: & 26 \\
\hline Género: & Masculino \\
\hline Ocupación: & Independiente
\end{tabular}

\section{Componente de caracterización}

1. ¿Cuál es su rol en el funcionamiento de este espacio cultural? ¿Cómo ingresa a hacer parte de él?

Secretario del cabildo, empecé colaborando con la digitación del censo y luego me ofrecieron ser el secretario.

2. ¿De qué manera se conforma el Cabildo Nasa en la ciudad de Bogotá y cuál es su propósito?

El cabildo se conforma por la asamblea, que son todos los cabildantes, los grupos de trabajo, la consejería y la directiva

\section{Componente de contextualización}

3. ¿Cómo se tejen vínculos de acción colaborativa entre este cabildo y el movimiento indígena Nasa que se encuentra en diversas latitudes del país?

Asistiendo a las actividades que los diferentes organismos como el CRIC organizan, tener contacto con los diferentes territorios, para que de esta manera se creen vínculos colaborativos 
4. Desde su posicionamiento particular, ¿cómo comprende la situación social, económica, política y cultural actual de la comunidad indígena Nasa en el país con énfasis en Bogotá?

En cuanto a lo económico es complejo porque hasta el momento no tenemos el registro en el ministerio del interior, o que significa que al cabildo no le lleguen recursos económicos del estado, por lo que para el sostenimiento económico y los gastos del cabildo se la tiene que rebuscar.

En cuanto a lo social, político y cultural nos regimos por nuestro plan de vida, en el cual se traza nuestro postura política, social y cultural, los cuales están encaminados al fortalecimiento de nuestra identidad como pueblo, la cual está en peligro de perderse debido al contexto de ciudad.

\section{Componente de opinión}

5. En sus palabras y asociando aquello que comentaba anteriormente respecto a la situación actual del pueblo Nasa, ¿cómo concibe los vínculos e, incluso, distanciamientos entre la labor informativa propia de los medios de comunicación nacional y las luchas y resistencias del movimiento indígena en los últimos años?

Es complejo que los medios de comunicación expresen las verdaderas intenciones de nuestro actuar, pues como es de conocimiento los grandes medios son propiedad de grandes empresarios que están al servicio de políticos y a ninguno de estos les beneficia informar lo que ocurre en realidad. También teniendo en cuenta que su visión occidental y centrada totalmente en el dinero no les permite entender nuestra cosmovisión como pueblos originarios, la cual no está enfocada en la económico, si en el bienestar y la armonía colectiva. 


\subsection{Entrevista a María Guetoto}

\subsection{Formato de entrevista semiestructurada dirigida a}

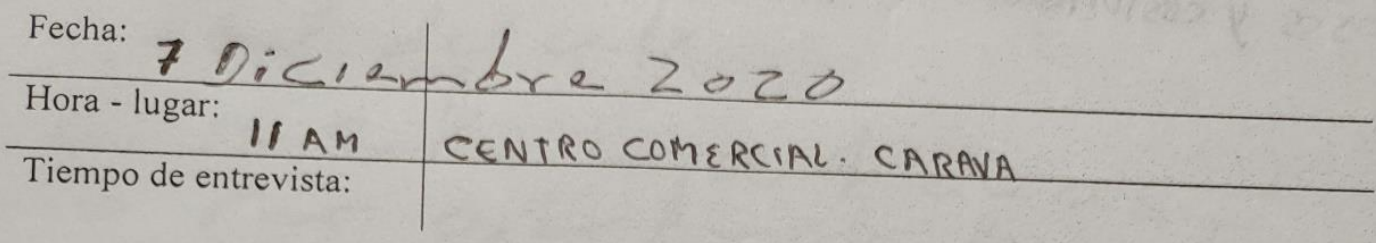

Generalidades del entrevistado

\begin{tabular}{l|l}
\hline Nombres y apellidos: & MARin Guetoto \\
\hline Edad: & 34 \\
\hline Género: & 7 EMENiÑo \\
\hline Ocupación: SEvicio & AL ClieNTE.
\end{tabular}

\section{Componente de caracterización}

1. ¿Cuál es su rol en el funcionamiento de este espacio cultural? ¿Cómo ingresa a hacer parte de él?

2. Desde su experiencia particular, ¿qué implica para usted pertenecer a esta comunidad indígena?

\section{Componente de contextualización}

3. Desde la conformación del Cabildo y su participación en él, ¿qué prácticas comunicativas ejercen para preservar su pensamiento como comunidad ancestral y dialogar con diversos actores sociales que integran o no el movimiento indígena?

\section{Componente de opinión}

4. Como integrante de la comunidad indigena, cha experimentado situaciones de violencia, menosprecio y desposesión de derechos por parte de otros actores del contexto urbano y rural? De ser afirmativo, ¿cuáles?

5. Respecto a lo anterior, ¿ha sido partícipe de situaciones de reconocimiento y valoración de su identidad ancestral y cultural? De ser afirmativo, ¿cuáles? 
1)

DARTICIPACIÓN EN LAS REUNIÓNES ATENCION AL CLENTE EN EL. LOCAL TAMBI ESTAR PENDIENTE DE LOS HijOS PARA qUE NO SE PIERDAN los OSCS Y COSTUMBRE DEL PUEBLO NASA

2)

PARA MI SIGNIFKA MUCHO COMPARTI CON LOS PAISANOS NASAS Hablar nuEStra lengua compartir apesar de que estamos EN LA CIGDAD ESTAR UNIDOS ES MUY IMPORTE.

para que mustros Hijos sigan al mismo camino de los mayore-

3)

para comonicar con los compañeros es can reunión o por celular tambien por parte nNa asamble general.

4)

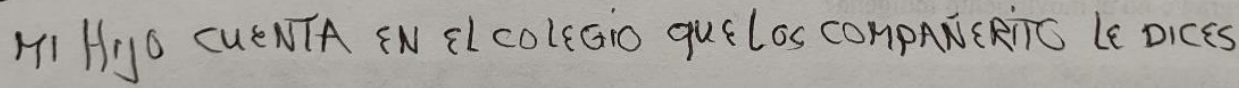
quE El ES INDIGENA QUE PORquE ESTUDIA CON LOS BLANCOS TAMBIEN CRITICAN MUKHO POR ELAPELliDO que El TIENE

5)

Por SER INDIGENA SOMO RECONOCiOdOS por \&l TRABajo LODigo porque HE TRATAdo con mochos CliENTE HAGENDO CONOC\&R CON LOS PRODUCTOS qUE VENGO MANEJADO COMO INDIGENA YA SOMOS RECONOCIDO ANIVEL NACONALL. 


\section{Diario de campo No. 1}

\begin{tabular}{|c|c|}
\hline Fecha & 7 de diciembre 2020 \\
\hline Lugar & Centro comercial caravana, centro de Bogotá \\
\hline Momento & Mañana 10 am \\
\hline Descripción de la experiencia & $\begin{array}{l}\text { Se entabla conversación informal con la integrante del } \\
\text { cabildo, maría Guetoto, preguntándole sobre los distintos } \\
\text { productos autóctonos de la comunidad nasa que vende en } \\
\text { un pequeño local de } 2 \mathrm{mts} \text { x } 2 \mathrm{mts} \text {, desde hace unos } \\
\text { meses, ella se encarga de todo lo relacionado al servicio } \\
\text { al cliente en ese local; luego se le explica que el motivo } \\
\text { de la visita es por cuestiones académicas, de manera } \\
\text { sencilla se le hace una breve introducción del trabajo } \\
\text { realizado, y se le solicita toda la colaboración, por } \\
\text { cuestiones de dinero, de tiempo, y de espacio, María, en } \\
\text { muchas ocasiones se lleva a su hijo para el local, lugar } \\
\text { donde hace las tareas, hace la siesta, y ayuda en las } \\
\text { ventas. } \\
\text { La interacción fue muy cordial, muy fructífera, María es } \\
\text { una persona muy amable, un poco tímida, sonriente, } \\
\text { puntual en lo que dice, entiende de la problemática } \\
\text { planteada, da su punto de vista, y desea que todo mejore } \\
\text { en el país, para el beneficio de su hijo. }\end{array}$ \\
\hline $\begin{array}{lll}\text { Comentarios } & \text { y } & \text { reflexiones } \\
\text { investigativas } & & \end{array}$ & $\begin{array}{l}\text { Considero que falta hacer más pedagogía sobre el rol que } \\
\text { cumplen las comunidades indígenas en Colombia entre } \\
\text { los mismos integrantes de dichas comunidades, en } \\
\text { especial, la que se está trabajando, ellos deben creer más } \\
\text { en sus tradiciones, en sus rasgos culturales. }\end{array}$ \\
\hline
\end{tabular}


Queda claro que la opinión y percepción que tienen de los medios hegemónicos no es la mejor, posiblemente es un enemigo que vencer, ya que, durante décadas, son ellos los que han construido una imagen negativa, $\mathrm{y}$ violenta sobre la comunidad nasa.

\section{Diario de campo No. 2}

\begin{tabular}{|c|c|}
\hline Fecha & 14 de diciembre 2020 \\
\hline Lugar & Casa de pensamiento indígena, centro de Bogotá \\
\hline Momento & $6 \mathrm{pm}$ \\
\hline Descripción de la experiencia & $\begin{array}{l}\text { Por razones de mucho trabajo, la charla fue bastante } \\
\text { puntual con la señora paulina mejía, quien es la } \\
\text { contadora encargada de la casa de pensamiento, quien } \\
\text { hace parte del cabildo nasa radicado en la ciudad, pero } \\
\text { colabora con otros cabildos indígenas, debido a su oficio, } \\
\text { se le explico de manera clara cuales son los objetivos del } \\
\text { trabajo académico, y se le socializo el cuestionario, el } \\
\text { cual accedió a diligenciarlo, mientras atendía una } \\
\text { reunión virtual con otras personas integrantes de otros } \\
\text { cabildos, sobre la gestión a realizar para el año venidero. }\end{array}$ \\
\hline $\begin{array}{lll}\text { Comentarios } & \text { y } & \text { reflexiones } \\
\text { investigativas } & & \end{array}$ & $\begin{array}{l}\text { El dialogar con integrantes del cabildo que hacen parte } \\
\text { del comité organizativo, da una mejor perspectiva sobre } \\
\text { todo lo que pasa al momento de organización y toma de } \\
\text { decisiones, saben de las dificultades sociales, políticas, y } \\
\text { económicas por las que vive constantemente los } \\
\text { cabildos, conocen de fondo las verdaderas intenciones de } \\
\text { las entidades gubernamentales, y reconocen cual es el }\end{array}$ \\
\hline
\end{tabular}


papel fundamental de los medios de comunicación poderosos, manipular a la opinión pública, encubrir y proteger a aquellos que dicen gobernar y hacerlo a la perfección. 


\section{BIBLIOGRAFÍA}

Agenda Propia. (2018). Bogotá indígena. Recuperado de: https://www.agendapropia.co/bogotaindigena

Alcaldía Mayor de Bogotá. (2011). Decreto 543 de 2011. Recuperado de: http://www.gobiernobogota.gov.co/sites/gobiernobogota.gov.co/files/documentos/multifunci onal/decreto_543_de_2011.pdf

Alto Comisionado de las Naciones Unidas para los refugiados. (s.f). Colombian situation indígenas. (Colombia, Costa Rica, Ecuador, Panamá y Venezuela). Recuperado de: https://www.acnur.org/fileadmin/Documentos/RefugiadosAmericas/Colombia/Situacion_Col ombia - Pueblos indigenas 2011.pdf

Bernal, M. (2012). Territorialidad nasa en Bogotá: apropiación, percepción y sentido de lugar. Cuadernos de Geografia. Revista Colombiana de Geografía, 21 (1), 83-98.

Bertaux, D. (2005). Los relatos de vida: perspectiva etnosociológica. Barcelona, España: Ediciones Bellaterra.

Briot, A. (2004). The luminious landscape, Columnas y artículos: Reflections on a Photography and Art. (En línea). Disponible en:

http://www.luminouslandscape.com/columns/Reflections-Introduction.shtml

Bresson, H. (2003). Fotografiar del natural. Recuperado de: https://www.academia.edu/36427909/Henri Cartier Bresson Fotografiar del natural

Capasso, V., Bugnone, A. (2016). Arte y política: un estudio comparativo de Jacques Rancière y Nelly Richard para el arte latinoamericano. Hallazgos, 13(26), 117-148 (doi: http://dx.doi.org/10.15332/s1794-3841.2016.0026.05).

Carrillo, A. (1997). La sistematización desde la perspectiva interpretativa. En Sistematización de experiencias. Búsquedas recientes. (pp. 25-79). Bogotá, Colombia: Dimensión Educativa.

Congreso de Colombia. (1991). Ley 21 de 1991. Recuperado de: https://www.renovacionterritorio.gov.co/librerias/media/pdf/normatividad/Ley21_1991.pdf 
DANE. (2019). Población indígena de Colombia. Resultados del Censo Nacional de Población y Vivienda $\quad$ - $\quad 2018.2$ Recuperado

https://www.dane.gov.co/files/investigaciones/boletines/grupos-etnicos/presentacion-gruposetnicos-2019.pdf

Franco, R. (2017). Los medios de comunicación como herramienta de lucha por el reconocimiento indígena. Recuperado de: https://www.researchgate.net/publication/314096807_Los_medios_de_comunicacion_como herramienta_de_lucha_por_el_reconocimiento_indigena

Fraser, N. (s.f.). ¿De la redistribución al reconocimiento? Dilemas de la justicia en la era «postsocialista». Recuperado de: https://newleftreview.es/issues/0/articles/nancy-fraser-de-la$\underline{\text { redistribution-al-reconocimiento-dilemas-de-la-justicia-en-la-era-postsocialista.pdf }}$

Giraldo, M. (2019). Cabildos indígenas, caminos y politica pública: una aproximación desde la sociología relacional. Recuperado de:

https://repository.javeriana.edu.co/bitstream/handle/10554/45174/Cabildos\%20ind\%C3\%AD genas $\% 2 \mathrm{C} \% 20 \mathrm{Caminos} \% 20 \mathrm{y} \% 20 \mathrm{Pol} \% \mathrm{C} 3 \%$ ADtica $\% 20 \mathrm{p} \% \mathrm{C} 3 \%$ BAblica $\% 20$ Una $\% 20$ Aproxi maci $\% \mathrm{C} 3 \% \mathrm{~B} 3 \mathrm{n} \% 20 \mathrm{desde} \% 201 \mathrm{a} \% 20$ Sociolog $\% \mathrm{C} 3 \% \mathrm{ADa} \% 20$ Relacional.pdf? sequence $=2 \&$ is Allowed $=\mathrm{y}$

Honneth, A. (1997). La lucha por el reconocimiento. Por una gramática moral de los conflictos sociales. Barcelona, España: Crítica.

Ministerio de cultura, Dirección de Comunicaciones, Gobierno de Colombia. (2017). Memorias del Encuentro de Escuelas y Procesos de Formación en Comunicación Indígena. Recuperado de: $\quad$ https://bancodecontenidos.mincultura.gov.co/comunicacionindigena/textos/memorias/memoria-encuentro-escuelas-formacion-comunicacionindigena.pdf

Molina, H. (2007). Nuevos escenarios de vida indígena urbana: el caso de Bogotá. Etnias y política, (4), 100-115.

Mora, P. (2015). Poéticas de la resistencia. El video indígena en Colombia. Bogotá, Colombia: Cinemateca Distrital.

Morales, A. (s.f). Nación Indígena. (Documental). Recuperado de: https://www.youtube.com/watch?v=tfpzBuX4oGA 
Morales, G. (2011). Los medios de comunicación vinculados a las estrategias de resistencia y afirmación cultural de los pueblos indígenas. Caso Kankuama tv. Saber, Ciencia y Libertad, (6), 1, (151-160).

Organización Nacional Indígena de Colombia ONIC., Ministerio de las Tecnologías de la Información y las Comunicaciones MinTIC. (2014). Política Pública de Comunicación Propia de los Pueblos Indígenas de Colombia. Recuperado de: https://criccolombia.org/foroipp/images/Politica-p-comunicacion-indi.pdf

Pérez, C., González, D. (2015). Comienzos y génesis. La Fotografía de Sebastiao Salgado. Revista Latente, 13, p. 9-18.

Salazar, N. (2018). Manipulación mediática y tratamiento informativo de las movilizaciones sociales indígenas en Cauca y Huila. Mediaciones, 14(20), 1-45.

Sampieri, R. (2014). Metodología de la investigación. México: Mc GrawHill.

Sanabria, M. Representaciones y autorrepresentaciones indígenas en los medios masivos de comunicación. Recuperado de: https://www.javeriana.edu.co/unesco/humanidadesDigitales/ponencias/pdf/IV_30.pdf

Secretaría de Cultura, Recreación y Deporte. (2015). Línea de base - plan de acción 2015-2020 Recuperado de: https://www.culturarecreacionydeporte.gov.co/sites/default/files/linea base plan de accia3n diciembre_2015.pdf

Secretaría de Integración Social. (2018). ¿Sabe usted que es una "casa de pensamiento intercultural"? Recuperado de: https://www.integracionsocial.gov.co/index.php/noticias/93noticias-infancia-y-adolescencia/2750-sabe-usted-que-es-una-casa-de-pensamientointercultural\#: :text=Las $\% 20$ Casas $\% 20 \mathrm{de} \% 20$ Pensamiento $\% 20$ Intercultural,de $\% 201 \mathrm{a} \% 20 \mathrm{co}$ munidad $\% 20$ en $\% 20$ general.

Secretaría Distrital de Planeación. (2005). Caracterización de la población indígena que reside en el distrito capital según censo de población 2005. Recuperado de: http://www.sdp.gov.co/sites/default/files/2005_caracte_censo.pdf

Shohat, E., Stam, R. (2002). Estereotipo, realismo y lucha por la representación. En: Multiculturalismo, Cine y Medios de Comunicación. (p. 185-220). Barcelona, España: Paidós. 
Sontag, S. (2006). Sobre la fotografía. México: Alfaguara. 